\title{
O heleninu od Srećka Bošnjakovića do Lavoslava Ružičke i najnovijih saznanja - ogledni primjer razvoja organske kemije u XX. stoljeću
}

\author{
V. Šunjić ${ }^{*}$ \\ Hrvatska akademija znanosti i umjetnosti, Zrinjski trg 11, 10000 Zagreb
}

DOI: $10.15255 /$ KUI.2016.008

KUI-4/2017

Pregledni rad

Prispjelo 1. ožujka 2016.

Prihvaćeno 11. travnja 2016.

\begin{abstract}
|| Sažetak
Prof. Srećko Bošnjaković (1865. - 1907.) prvi je kemičar u Hrvatskoj koji je izradio disertaciju na području organske kemije. U svojoj disertaciji objavljenoj 1893. pod naslovom “Gerhardtov helenin" Bošnjaković opisuje izolaciju helenina iz korijena biljke Inula helenium L., razdvajanje kemijski čistih supstancija i određivanje njihovih empirijskih formula elementarnom analizom. $U$ disertaciji uz helenin koristi se i imenom alantolakton, koje se kasnije gotovo isključivo pojavljuje u literaturi. Budući da taj naziv ukazuje na postojanje laktonske skupine u heleninu, smatrao sam zanimljivim istražiti što je bilo poznato o toj strukturi u vrijeme Bošnjakovićevog rada na disertaciji te tko je točno odredio strukturu alantolaktona kao i nekih izomernih i srodnih spojeva koji se nalaze u prirodi. Pokazalo se da je velik doprinos tom području dao naš nobelovac Lavoslav Ružička, koji je u razdoblju 1931. - 1936. intenzivno istraživao strukture brojnih seskviterpena i postavio poznato Ružičkno biogenetsko izoprensko pravilo (L. Ružička, The isoprene rule and the biogenesis of terpenic compounds, Experientia 9 (1953) 357-396).

Potaknut tom neočekivanom "hrvatskom vezom preko helenina" naišao sam na niz zanimljivih podataka o kasnijem razvoju kemije vezane uz helenin ili alantolakton, a posebno o doprinosu Lavoslava Ružičke određivanju strukture. U ovom pregledu detaljnije su opisana istraživanja Bošnjakovića na izolaciji alantolaktona i Ružičkina istraživanja na određivanju njegove strukture. Slijedi prikaz određivanja strukture, sinteze i najnovijih saznanja o vrlo značajnom biološkom djelovanju alantolaktona i njegovih srodnika. Put do najnovijih saznanja izvrstan je primjer razvoja organske kemije u XX. stoljeću.
\end{abstract}

\| Ključne riječi

Inula helenium L., helenin, alantolakton, struktura, stereokemija, biološko djelovanje, povijest kemije

\section{Uvod}

Ljekovita svojstva korijena biljke Inula helenium L., kod nas poznate pod brojnim imenima, alant, aman, bijeli oman, devesil, lepuh, ivanjsko zelje, veliki korijen, bila su poznata od antičkih vremena. Tako Plinije stariji predlaže svakodnevno žvakanje tog korijena zbog bolje probave, očuvanja zubnog mesa i liječenja išijasa. ${ }^{9}$ Tradicionalno se korijen omana ekstrahirao vrućom vodom ili vinom te su uz različite dodatke pripravljani napitci za liječenje bronhitisa, astme, za olakšano mokrenje, protiv šećerne bolesti i kožnih oboljenja. ${ }^{2}$ Posebno je cijenjeno "omanovo vino", ekstrakt u alkoholu, obično u komovici uz naknadni dodatak vina. Upotrebljavano je u ratovima kao stimulans vojnicima pred bitku, a u miru kao ljekovit vinski napitak osvježavajućeg okusa. Zbog velike vrijednosti na tržištu njegova je proizvodnja u srednjem vijeku povremeno monopolizirana od strane kraljeva i velmoža. Danas je još cijenjen alkoholni napitak absinthe, liker poznat na svjetskom tržištu, koji se najviše proizvodi u Švicarskoj, Francuskoj i Nizozemskoj. Ljekovita svojstva ekstrakta korijena omana bila su od davnina poznata i na Dalekom istoku, gdje je biljka uzgajana u poljima i vrtovima te naveliko prerađivana za raznovrsnu medicinsku primjenu. ${ }^{3}$

\section{Bošnjakovićeva disertacija - što je to helenin ili alantolakton?}

U povodu obilježavanja 150. godišnjice rođenja prof. Srećka Bošnjakovića (slika 1) organiziran je u Hrvatskoj akademiji znanosti i umjetnosti 24. studenoga 2015. znanstveni skup. $^{4}$

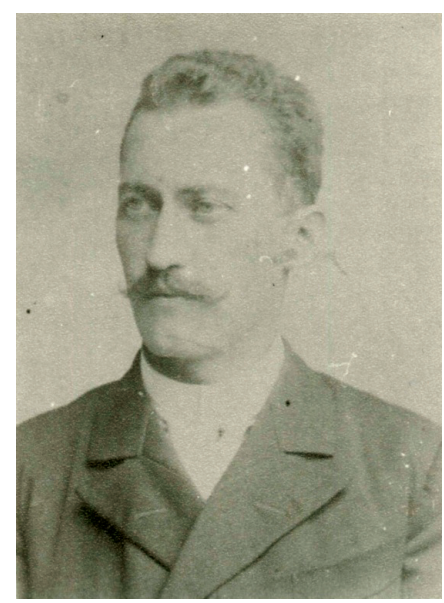

Slika 1 - Fotografija S. Bošnjakovića, vjerojatno iz razdoblja rada na disertaciji

Fig. 1 - Photo of S. Bošnjaković, presumably from the period of his work on his Ph. D. Thesis 


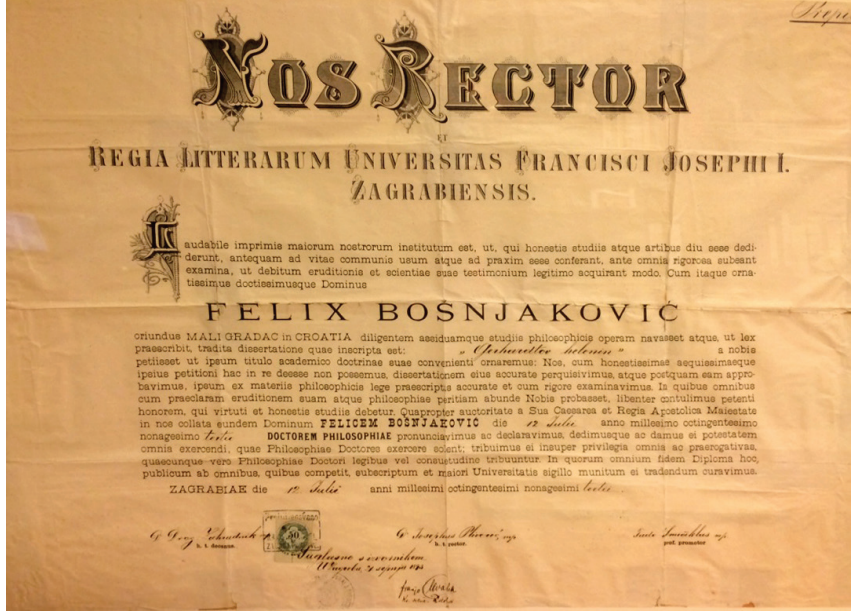

Slika 2 - Doktorska diploma dodijeljena 1893. S. Bošnjakoviću Fig. 2 - Ph. D. diploma awarded to S. Bošnjaković in 1893

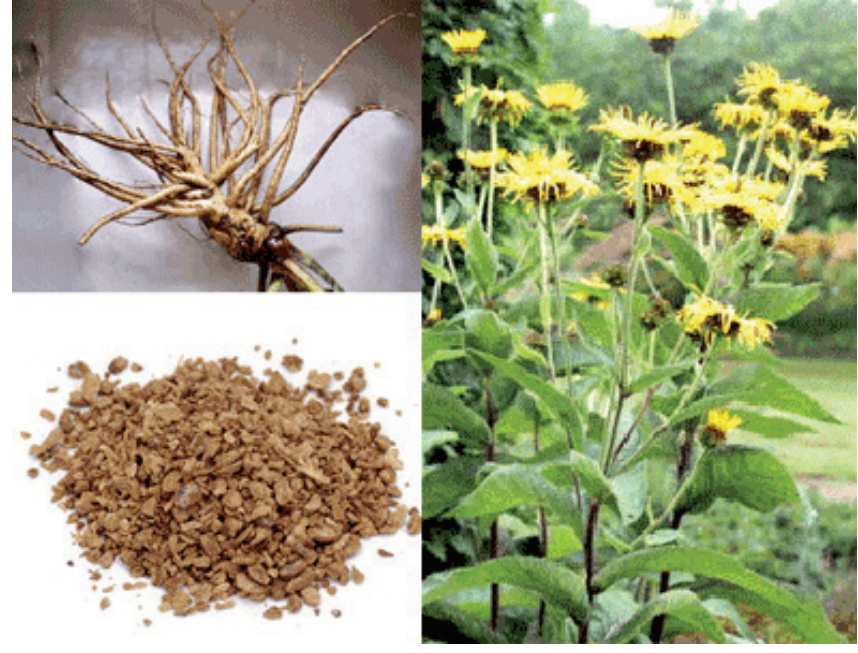

Slika 3 - Korijen i stabljika Inula helenium L.

Fig. 3 - Root and stem of Inula helenium L.

Detaljno se opisuje proces ekstrakcije mljevenog korijena biljke Inula helenium L. u narodu poznate pod brojnim imenima, najčešće alant ili aman. Može narasti do $2 \mathrm{~m}$ i posjeduje gomoljasti korijen koji uz helenin sadrži i brojne druge biološki aktivne spojeve (slika 3).

Posebno je zanimljiva Bošnjakovićeva opaska u disertaciji da je istraživanja započeo mljevenjem $27 \mathrm{~kg}$ (!) korijenja Inula helenium L. te digeriranjem u etanolu, filtracijom i taloženjem skupljao pojedine frakcije. Ove je brojnim kristalizacijama iz etanola $\mathrm{i}$ vode dalje pročišćavao do kristaličnih uzoraka s više-manje konstantnim talištem kao jedinim indikatorom čistoće uzorka. Za alantolakton Bošnjaković je u disertaciji potvrdio formulu $\mathrm{C}_{15} \mathrm{H}_{20} \mathrm{O}_{2}$, predloženu od Gerhardta (slika 4).

Elementarnoj analizi podvrgnuta daje zaključiti na empir. formulu $\mathrm{C}_{15} \mathrm{H}_{20} \mathrm{O}_{2}$, onu istu, što ju podaje i Gerhardt svomu heleninu tališta $72^{\circ} \mathrm{C}$, Kallen svomu anhidridu alantove kiseline tališta $66^{\circ} \mathrm{C}$, i Posth svomu alantolaktonu tališta $76^{\circ} \mathrm{C}$, i ssto približno odgovara brojevima, dobivenim spaljenjem Janečkove tvari tališta $67 \cdot 1^{\circ} \mathrm{C}$.

Rezultati elementarne analize moje tvari, sušene $u$ vakuumu nad $\mathrm{H}_{2} \mathrm{SO}_{4}$ do konstantne težine jesu sliedecei :

I. $0.2068 \mathrm{~g}$ tvari : $0.5891 \mathrm{~g} \mathrm{CO}_{\mathrm{g}}, 0.1633 \mathrm{~g} \mathrm{H}_{2} \mathrm{O}$

II. $0.2156 \mathrm{~g}$ tvari : $0.6149 \mathrm{~g} \mathrm{CO}_{2}, 0.1675 \mathrm{~g} \mathrm{H}_{2} \mathrm{O}$

III. $0.2279 \mathrm{~g}$ trari : $0.6468 \mathrm{~g} \mathrm{CO}_{2}, 0.1757 \mathrm{~g} \mathrm{H}_{2} \mathrm{O}$

Nadjeno:

\begin{tabular}{lrrrc} 
& \multicolumn{1}{c}{} & & & Računano za \\
$\mathrm{C}$ & \multicolumn{1}{c}{ I. } & II. & III. & $\mathrm{C}_{15} \mathrm{H}_{20} \mathrm{O}_{2}:$ \\
$\mathrm{H}$ & 8.77 & $77 \cdot 78$ & $77 \cdot 40$ & 77.59 \\
$\mathrm{O}$ & 13.54 & 13.63 & 8.56 & 8.62 \\
& & & 14.04 & 13.79
\end{tabular}

Slika 4 - Izvadak iz disertacije, gdje se upotrebljavaju nazivi helenin, anhidrid alantove kiseline i alantolakton za spoj empirijske formule $\mathrm{C}_{15} \mathrm{H}_{20} \mathrm{O}_{2}$

Fig. 4 - Excerpt from Ph. D. Thesis where the names helenine, alantoic acid anhydride, and alantolactone are used for the compound of the empirical formula $\mathrm{C}_{15} \mathrm{H}_{20} \mathrm{O}_{2}$ 
Istodobnu upotrebu naziva anhidrid i lakton, iako prva skupina sadrži tri, a druga samo dva kisikova atoma, Bošnjaković je preuzeo iz jednog ranijeg rada. Međutim zapazio je da se u smjesi s alantolaktonom javlja spoj koji prema elementarnoj analizi sadrži treći kisikov atom i nazvao ga je oksialantolakton, a ne anhidrid (slika 5). Struktura tog spoja određena je skoro 100 godina kasnije!

nidin je nadalje bez teka i mirisa, kristalizira dendritički“.

Buduć sam bio u posjedu tako male količine ove, od samoga dra. Janečka pripravljene tvari, da sam mogao tek jednu elementarnu analizu izvesti: ne ce biti naravno ni empirička formula, na temelju te analize proračunana, posve pouzdana. Evo rezultata te analize :

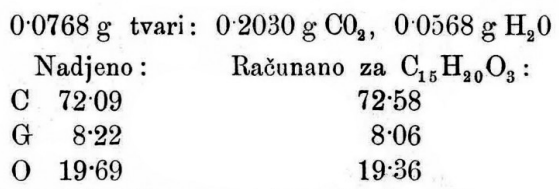

Po tom bi taj helenidin mogao biti oksialantolakton, postao oksidacijom alantolaktona na zraku.

Slika 5 - Izvadak iz disertacije, gdje se uporebljava ime oksalantolakton za spoj empirijske formule $\mathrm{C}_{15} \mathrm{H}_{20} \mathrm{O}_{3}$

Fig. 5 - Excerpt from thesis where the name oxyalantolactone is used for the compound of empirical formula $\mathrm{C}_{15} \mathrm{H}_{20} \mathrm{O}_{3}$

U disertaciji se nadalje opisuje izolacija natrijeve soli kiseline dobivene hidrolizom alantolaktona te priprava slobodne kiseline empirijske formule $\mathrm{C}_{15} \mathrm{H}_{22} \mathrm{O}_{3}$ (slika 6).

U vodenoj otopini $\mathrm{NaOH}$ tvar je za hlada netopiva, ali se raztapa grijanjem, a iz te se raztopine, kad je dovoljno razriedjena i suvišna $\mathrm{NaOH}$ oprezno kojom kiselinom neutralizovana, ohladjenjem i stajanjem izlučuju pahulje mikroskopskih, igličastih kristala, svjetlucavih, lako topivih u hladnoj a još laglje u toploj vodi.

Nekolikoputnim prekristalizovanjem čišćena, zatim sušena u eksikatoru do konstantne težine i spaljena uz dodatak $\mathrm{H}_{2} \mathrm{SO}_{4}$ daje:

$0.2342 \mathrm{~g}$ tvari: $0.0602 \mathrm{~g} \mathrm{Na}_{2} \mathrm{SO}_{4}$, što čini $8.33 \% \mathrm{Na}$, a formula $\mathrm{C}_{15} \mathrm{H}_{21} \mathrm{O}_{3} \mathrm{Na}$ zahtieva $8 \cdot 46 \% \mathrm{Na}$.

Slika 6 - Opis hidrolize alantolaktona i određivanje postotka natrija u soli

Fig. 6 - Description of hydrolysis of alantolactone and determination of sodium percentage in the salt

Iz anhidrida pripravljen je amid, a iz slobodne kiseline srebrove i barijeve soli. U zaključku disertacije Bošnjaković ističe da objavljuje samo dio svojega rada te se nada nastaviti istraživanja (slika 7).

No on nije uspio nastaviti istraživanja alantolaktona i srodnih spojeva. Zivotni put odveo ga je prema osnivanju privatnog laboratorija, danas bi rekli kontrolno-analitičkog laboratorija, za utvrđivanje kvalitete vode, vina, i niza drugih proizvoda iz poljoprivrede i šumarstva, a zatim i prema akademskoj karijeri. ${ }^{7,8}$
Za sada objelodanjujem ovaj dio svoga rada sa nakanom, da $\mathrm{i}$ ostale frakcije proučim, čim mi vrieme bude dopustilo. Ako ne uspijem, da frakcionovanom kristalizacijom iz preostalog mi materijala posve odstranim gore nabrojene slučenine i izoliram one, koje, kako se čini, u pretežnoj količini sačinjavaju sirovi helenin, pokušati ću frakcionovanim taloženjem odnosno kristalizacijom kojega derivata to postići, pri čem bih se i mogao nadati, da ću laglje do cilja doći.

Slika 7 - Zaključni stavak iz Bošnjakovićeve disertacije

Fig. 7 - Final statement in Bošnjaković's thesis

Pregledom objavljenih radova o heleninu prije i u vrijeme izrade Bošnjakovićeve disertacije uočio sam da je i Gerhardt u svojem radu navodio samo empirijske formule i koristio se nazivom helenin. ${ }^{6}$ Njegov eksperimentalni pristup primijenio je i Bošnjaković, a kao dokaz identiteta pročišćenih spojeva oba navode samo $\mathrm{CH}$-analize. Određeni napredak postigao je J. Kallen, koji je pročišćeni spoj formule $\mathrm{C}_{15} \mathrm{H}_{20} \mathrm{O}_{2}$ označio kao alantkamfor, helenin, ali $\mathrm{i}$ anhidrid alantove kiseline. ${ }^{9}$ Njegov rad citira Bošnjaković u svojoj disertaciji. No Kallen čini zanimljivu pogrešku, helenin naziva $\mathrm{i}$ anhidridom alantove kiseline, vjerojatno na osnovi njegove lake hidrolize u baznom mediju, iako bi empirijska formula trebala sadržati tri O-atoma! Taj "anhidrid" on hidrolizira u kiselinu ili amonolizom u amid, a iz kiseline pripravlja niz soli, slično rezultatima koje opisuje S. Bošnjaković.

Vrlo je zanimljivo da je prvi put ime alantolakton predložio W. Posth u svojoj disertaciji objavljenoj 1892. i zatim u radu iz 1895., dakle istodobno s Bošnjakovićevim radom na disertaciji. Bošnjaković Posthovu disertaciju poznaje i citira te se vjerojatno potaknut njome koristi imenom alantolakton. $U$ prethodno objavljenom radu Posth prvi put daje zanimljiv prikaz djelomične strukturne formule alantolaktona (slika 8). ${ }^{10}$

schiedenes zum Ausdruck bringen. Wie bereits bemerkt, gab Kallen der aus dem Helenin Gerhardt's erhaltenen Säure den Namen Alantsäure; da nun durch nachfolgende Untersuchung erwiesen wird, dass diese Säure eine Oxysäure ist,

welche sich sehr leicht in das ihr entsprechende Lacton umwandelt, so soll die Oxysäure den Namen Alantolsäure und ihr Lacton - das Helenin - die Bezeichnung Alantolacton erhalten.

Lacton und Essigsäureanhydrid zurück. Durch Erwärmen mit Alkalien geht das Alantolacton in das Alkalisalz der Oxysäure über, gemäss der Gleichung:

$$
\mathrm{C}_{14} \mathrm{H}_{20}<{ }_{\mathrm{CO}}^{\mathrm{O}}+\mathrm{NaOH}=\mathrm{C}_{14} \mathrm{H}_{20} \succ_{\mathrm{COONa}}^{\mathrm{OH}} .
$$

Slika 8 - Posthova argumentacija za ime alantolakton i prijedlog formule ${ }^{10}$

Fig. 8 - Posth's argumentation for the name alantolactone and proposed formula ${ }^{10}$ 
On dakle također ne zna strukturu alantolaktona, ali pretpostavlja postojanje laktonske skupine te provodi amonolizu i daje reakcijsku shemu (slika 9).

4) a. Durch Einwirkung von alkoholischem Ammoniak in der Kälte auf das Alantolacton erhält man das Amid der 0xysäure, nach der Formel

$$
\mathrm{C}_{14} \mathrm{H}_{20}<{ }_{\mathrm{CO}}^{\mathrm{O}}+\mathrm{NH}_{3}=\mathrm{C}_{14} \mathrm{H}_{20}<{ }_{\mathrm{CONH}_{2}}^{\mathrm{OH}} .
$$

Slika 9 - Opis pokusa i reakcijska shema amonolize alantolaktona $^{10}$

Fig. 9 - Description of the experiment and reaction scheme for ammonolysis of alantolactone $\mathrm{e}^{10}$

Bošnjaković međutim u svojoj disertaciji ne upotrebljava tu "parcijalnu" strukturnu formulu alantolaktona.

Zanimljivo je da se nakon tih radova skoro 40 godina ne pojavljuju radovi s područja kemije i strukture alantolaktona. Tek nakon 1930. godine drugi hrvatski organski kemičar nobelovac Lavoslav Ružička u svojim radovima o prirodnim spojevima, posebno terpenima i seskviterpenima, pristupa istraživanju alantolaktona.

\section{Ružičkin doprinos poznavanju strukture - kako zapravo izgleda seskviterpen alantolakton?}

Potvrdivši u disertaciji empirijsku formulu alantolaktona $\left(\mathrm{C}_{15} \mathrm{H}_{20} \mathrm{O}_{2}\right)$, priredivši amid i neke soli odgovarajuće kiseline te ukazavši na prisutnost oksialantolaktona $\left(\mathrm{C}_{15} \mathrm{H}_{20} \mathrm{O}_{3}\right)$ u ekstraktu korijena Inula helenium L., Bošnjaković je dao vrijedan doprinos poznavanju prirodnih spojeva iz skupine seskviterepena. No ostao je otvoren niz pitanja vezanih uz strukturu i stereokemijsku građu alantolaktona na koja u to vrijeme nije bilo moguće dati odgovor dostupnim metodama u sintetskoj i analitičkoj organskoj kemiji. Ovdje navodimo najvažnija:

- kako je izgrađen $\mathrm{C}_{15}$-ugljikov kostur alantolaktona

- koliko prstena ili višestrukih veza sadrži

- koja je relativna konfiguracija oko C-atoma; cis/trans, E/Z

- koja je apsolutna konfiguracija na kiralnim centrima, asimetričnim C-atomima; R ili S?

Točne odgovore na ta pitanja dala je moderna organska kemija tek nakon 1950. godine, o čemu je riječ i u sljedećem poglavlju. Ipak prvu strukturnu formulu alantolaktona predlaže Ružička i daje odgovore na neka od gore postavljenih pitanja u okviru svojih radova na području seskviterpena objavljenih 1931. - 1933. ${ }^{11-13}$ Sigurno je da su ta istraživanja seskviterpena doprinijela Ružičkinu ukupnom znanstvenom opusu za koji mu je 1939. dodijeljena Nobelova nagrada (slika 10).

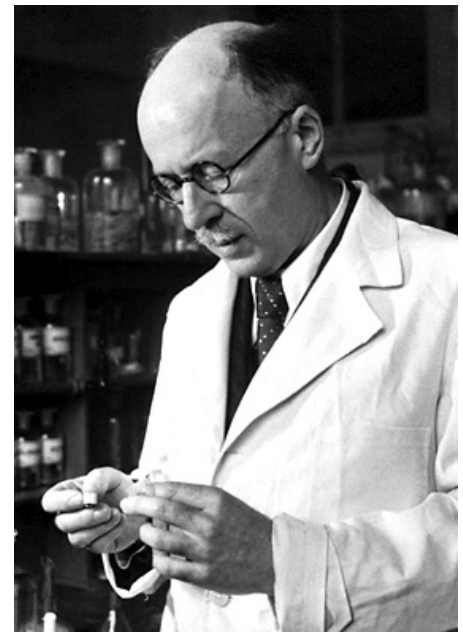

Slika 10 - Prof. Lavoslav Ružička (1887. - 1976.), dobitnik Nobelove nagrade 1939.

Fig. 10 - Prof. Lavoslav Ružička (1887-1976), 1939 Nobel laureate

Zanimljivo je dakle da su dva hrvatska kemičara u razmaku od skoro pola stoljeća istraživala strukturu tog prirodnog spoja i tako postavila temelje suvremenim znanjima na tom području.

U prvim radovima o alantolaktonu Ružička je predložio strukture I i II za alantolakton i izoalantolakton (slika 11). ${ }^{11}$ Obje su se kasnije pokazale djelomično pogrešnim kako s obzirom na položaj aneliranog laktonskog prstena na dekalinski skelet, tako i s obzirom na položaj jedne dvostruke veze.

Auf Grund der bisher vorliegenden experimentellen Ergebnisse konnte man mit grosser Wahrscheinlichkeit für das Alantolacton Formel I und für das Iso-alantolacton Formel II ableiten ${ }^{2}$ ):
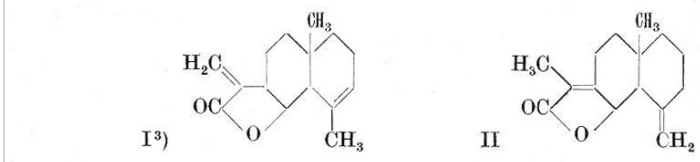<smiles>C=C1C(=O)OC2C1CCC1(C)CCC=C(C)C21</smiles><smiles>C=C1CCCC2(C)CCC3=C(OC(=O)C3C)C12</smiles>

Slika 11 - Ružičkin prijedlog formula alantolaktona i izoalantolaktona ${ }^{11}$ te iste formule orijentirane u skladu s IUPAC-ovim pravilima o prikazu policikličkih spojeva

Fig. 11 - Ružičkass proposal for the formula of alantolactone and isoalantolactone, ${ }^{11}$ and the same formulas oriented according to IUPAC rules for polyclic compounds

Pokušat ćemo razumjeti razloge za tako pretpostavljenu strukturu. U to vrijeme Ružička je postavio svoje zname- 
nito izoprensko pravilo koje kaže "ugljikov skelet terpena izgrađen je od izoprenskih jedinica u regularnom ili iregularnom slijedu" (slika 12). ${ }^{14}$

Primjer za biokatalitičku polimerizaciju tri mola izoprena u seskviterpene prikazana je na slici 13.

Ako pretpostavimo da je u to vrijeme bio poznat jednostavan izraz za računanje ekvivalenata dvostruke veze (EDV), tj. broja dvostrukih veza i prstena u molekuli poznate empirijske formule, tada je prema tom izrazu iz empirijske formule alantolaktona bilo lako odrediti da sadrži 6 EDV, slika 14.

Možemo zaključiti da je Ružička pretpostavio strukturu dekalina u molekuli alantolaktona te peteročlani lakton. Tako dobivamo definirana četiri EDV, tri prstena i vezu $\mathrm{C}=\mathrm{O} u$ laktonu. Preostala dva ekvivalenta nezasićenosti velikom vjerojatnošću pripadaju dvjema vezama $C=C$. Sada se javlja pitanje detaljnije strukture, gdje je priključen laktonski prsten na dekalinski segment i gdje se nalaze dvostruke veze (slika 14)? Na prijedlog struktura I i II za alantolakton i
2<smiles>C=C(C)C=CC</smiles>

izopren isoprene
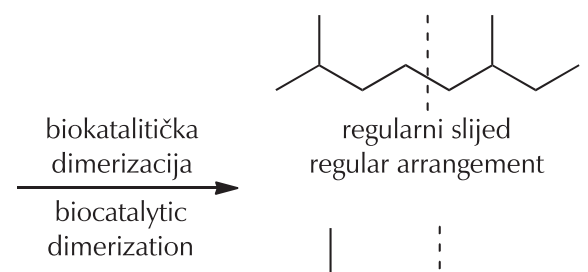

regularni slijed regular arrangement<smiles>CC(C)CCCCC(C)C</smiles>

$$
\text { irregular arrangement }
$$

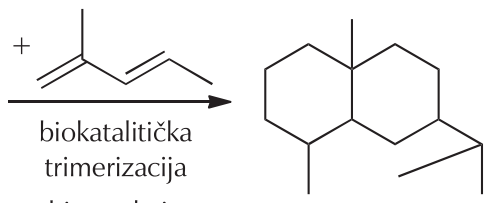

biocatalytic trimerization

Slika 12 - Opća shema za izoprensko pravilo, nastajanje diterpena i seskviterpena

Fig. 12 - General scheme for the isoprene rule, formation of diterepenes and sesquiterpenes

primjer za Ružičkino izoprensko pravilo
an example of Ruzicka's isoprene rule<smiles>C=CC(=C)C</smiles>

izopren isoprene<smiles>CC(C)=CCCC(C)=CCCO</smiles>

farnezil pirofosfat farnesyl pyrophosphate<smiles>C#CCCCCCCCCCC</smiles>

osnovni skelet seskviterpena eudesmola i santonina

Slika 13 - Polimerizacije izoprena u seskviterpene

Fig. 13 - Polymerization of isoprene to sesquiterepenes

osnovna saznanja o strukturi alantolaktona,

dostupna na osnovi empirijske formule i Ružičkina terpenskog pravila

basic knowledge of the structure of alantolactone,

based on the empirical formula and Ruzicka's terpene rule

elementi nezasićenosti,

ekvivalent dvostruke veze (EDV)

$\mathrm{EDV}=\Sigma$ dvostruke veze + prstenov

$\mathrm{C}_{a} \mathrm{H}_{b}\left(\mathrm{O}_{c}\right) \quad E D V=\frac{(2 a+2)-b}{2} \quad \mathrm{C}_{15} \mathrm{H}_{20}\left(\mathrm{O}_{2}\right) \Rightarrow E D V=6 !$

elements of unsaturation,

double bond equivalent (DBE)

$\mathrm{DBE}=\Sigma$ double bonds + rings

$$
\mathrm{C}_{a} \mathrm{H}_{b}\left(\mathrm{O}_{c}\right) \quad \mathrm{DBE}=\frac{(2 \mathrm{a}+2)-b}{2} \quad \mathrm{C}_{15} \mathrm{H}_{20}\left(\mathrm{O}_{2}\right) \Rightarrow \text { DBE }=6 !
$$

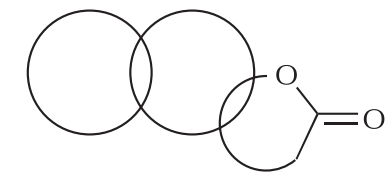

$\mathrm{EDV}=$ tri prstenova $+\mathrm{C}=\mathrm{O}=4$

do $\mathrm{EDV}=6$ treba odrediti položaj dviju dvostrukih veza!

$\mathrm{DBE}=$ three rings $+\mathrm{C}=\mathrm{O}=4$

for $\mathrm{DBE}=6$ we need to now the position of the two double bonds!

struktura dekalina

lakton

structure of decaline

lactone

Slika 14 - Mogući put prema prvom prijedlogu strukture alantolaktona

Fig. 14 - Possible route to the first proposal of the structure of alantolactone 
izoalanolakton s 5-eročlanim laktonskim prstenom Ružička je vjerojatno bio potaknut i radovima Clemoa i Hawortha u kojima je određena struktura santonina i tetrahidrosantonina (slika 15). ${ }^{15} \mathrm{U}$ tim strukturama potvrđen je angulirani položaj laktonskog prstena, što je vjerojatno potaklo Ružičku na prijedlog struktura I i II u slici 11.<smiles>CC1=C2C3OC(=O)C(C)C3CCC2(C)C=CC1=O</smiles>

santonin santonin<smiles>CC1C(=O)OC2C1CCC1(C)CCC(=O)C(C)C21</smiles>

tetrahidrosantonin tetrahydrosantonin
Slika 15 - Strukture santonina i tetrahidrosantonina ${ }^{15}$

Fig. 15 - Structures of santonine and terahydrosantonine $e^{15}$

lako su se strukture alantolaktona i izoalantolaktona pokazala pogrešnim, priprava čistih uzoraka zahtijevala je enorman eksperimentalni rad. Ružička navodi u eksperimentalnom dijelu jednog rada da je za pripravu čistog alantolaktona bilo potrebno provesti oko 300 kristalizacija (slika 16)! ${ }^{12}$

Zuerst krystallisierte das schwerlösliche Dihydro-iso-alantolacton aus, dann das Iso-alantolacton und schliesslich das Alantolacton, dessen Reinigung am meisten Schwierigkeiten machte. Es waren dazu etwa 300 Krystallisationen nötig. Die Präparate wurden bis zum

Slika 16 - Izvadak iz eksperimentalnog dijela Ružičkinog rada u Helv. Chim. Acta 1931.12

Fig. 16 - Detail from the experimental part of the Ružička paper in Helv. Chim. Acta $1931^{12}$

Strukture I i II Ružička želi potvrditi 1933. god. u svojem sljedećem radu iz područja seskviterpena i to reakcijama odgradnje i hidrogenacije do spojeva poznate strukture, dakle kemijskom korelacijom. ${ }^{13}$ Posebno je zanimljiv postupak dokazivanja strukture I pripravom derivata III - V (slika 17). ${ }^{13}$
III

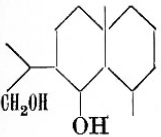

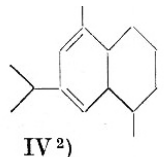

IV $\left.{ }^{2}\right)$

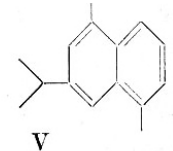

$\mathrm{V}$
Slika 17 - Ružičkin prijedlog dokaza strukture alantolaktona I prevođenjem u spojeve III - V ${ }^{13}$

Fig. 17 - Ružička's proposal for proving the structure of alantolactone I by transformation to compounds III-V

Spojevi III i IV derivati su potpuno i djelomično hidriranog naftalena, a spoj $\mathbf{V}$ je trialkilirani naftalen. Njihova priprava iz pretpostavljene strukture alantolaktona prikazana je $u$ shemi 1, na osnovi podataka koje daje Ružička u svojem originalnom radu. ${ }^{13}$

Strukturu 1,5-dimetil-7-izopropil naftalena V dokazao je neovisnom sintezom, dok migraciju metilne skupine $\mathrm{s}$ atoma u premoštenju na atom C(5) tumači "pregradnjom pinakolnog tipa iscrpno bromiranog intermedijara". Bitno je međutim uočiti da spojevi IV i V ne otkrivaju ni položaj dvostrukih veza niti položaj aneliranog laktonskog prstena u polaznom alantolaktonu. Stoga zapravo te transformacije ne potvrđuju jednoznačno predloženu strukturu I!

Možemo zaključiti da su Ružičkini radovi predstavljali velik doprinos razumijevanju strukture politerpena, posebno seskviterpena, iako u njima nije potpuno točno određena struktura alantolaktona i izoalantolaktona. Trebalo je proći četvrt stoljeća dok moderne sintetske i spektroskopske metode u organskoj kemiji nisu omogućile korekciju strukture tih spojeva. Nakon toga se pristupilo i određivanju relativne $i$ apsolutne konfiguracije $u$ enantiomerno čistom prirodnom (+)-alantolaktonu za koji su u posljednjim desetljećima zapažena brojna zanimljiva biološka djelovanja.<smiles>C=C1C(=O)OC2C1CCC1(C)CCC=C(C)C21</smiles>

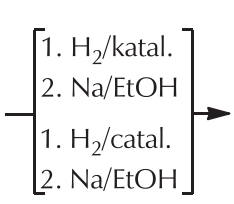<smiles>CC1=CC(C(C)C)=CC2C(C)CCCC12</smiles>

IV<smiles>CC(CO)C1CCC2(C)CCCC(C)C2C1O</smiles>

III<smiles>Cc1cc(C(C)C)cc2c(C)cccc12</smiles>

Shema 1 - Ružičkin prikaz transformacije pretpostavljenog alantolaktona I u spojeve III - V $\mathbf{1 3}^{3}$ Scheme 1 - Ružičkaıs presentation of the transformation of proposed alantolactone I to compounds III-V 
Opaska. Zanimljivo je da D. Grdenić, pišući o S. Bošnjakoviću (Kem. u Ind. 42 (1993) 171-186), ne opaža da je Ružičkin prijedlog strukture alantolaktona dijelom pogrešan! Grdenić kaže: "Vrijedi spomenuti da je strukturu alantolaktona odredio L. Ružička sa suradnicima četrdeset godina kasnije: Helv. Chim. Acta 14 (1931) 1090, ibid. 16 (1933) 268. Potvrdili su formulu $\mathrm{C}_{15} \mathrm{H}_{20} \mathrm{O}_{2}$ koju je odredio Bošnjaković, ali ga nisu citirali. Za njegov članak objavljen u Radu JAZU 113 (1893) 140, nisu znali. Nije bio referiran u Chem. Zentralblattu".

Zahvaljujem prof. S. Paušek-Baždar koja me upozorila na ovaj tekst akademika D. Grdenića.

\section{Novija strukturna istraživanja alantolaktona}

Ispravno određivanje strukture i stereokemijske građe alantolaktona omogućio je napredak sintetskih i spektroskopskih metoda u organskoj kemiji u drugoj polovici prošlog stoljeća. Tomu su slijedile sinteze alantolaktona i izoalantolaktona, oba u racemičnom obliku, te istraživanja bioloških svojstava i priprava njihovih derivata, o čemu se govori u sljedećem poglavlju.
Ovdje ćemo prvi put pokazati danas prihvaćene strukture alantolaktona 1, izoalantolaktona 2 i oksialantolaktona 3, spojeva koje još u svojoj disertaciji spominje S. Bošnjaković, dok je strukturu prvoga pokušavao odrediti L. Ružička!

Alantoakton 1 i izoalantolakton 2 sadrže četiri kiralna, stereogena ili asimetrična centra, a oksialantolakton čak 6 . Na slici 18 uz formulu 1 navedeno je puno kemijsko ime alantolaktona i numeracija prema IUPAC-u. Navedene su danas prihvaćene apsolutne konfiguracije na kiralnim centrima. Dakle četiri asimetrična centra u prirodnom (+)-alantolaktonu posjeduju konfiguraciju $3 \mathrm{a} R, 5 S, 8 \mathrm{a} R, 9 \mathrm{a} R$. Ovdje se primjenjuje danas prihvaćena Cahn-Ingold-Prelogova (CIP) konvencija. ${ }^{16}$

Dug je bio put kojim se došlo do strukture alantolaktona 1, tražio se niz sintetskih korelacija sa spojevima poznate strukture i spektroskopskih podataka.

Prvom sintetskom korelacijom s eudesmolom određena je $(R)$-apsolutna konfiguracija na $\mathrm{C}(3 \mathrm{a})$ i $\mathrm{C}(8 \mathrm{a})$ atomima u premoštenjima alantolaktona. ${ }^{17}$ Time je pokazano da metilna skupina u premoštenju dekalona zauzima $\beta$-položaj, tj. iznad ravnine planarne strukture, kako je utvrđeno za niz seskviterpena i steroida. Apsolutna konfiguracija eudesmola utvrđena je na osnovi sinteze iz optički istog (-)-trans-dekalona. ${ }^{17,18}$
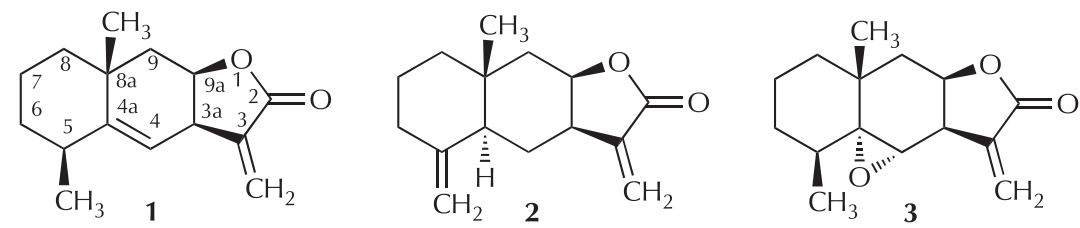

Slika 18 - (+)-Alantolakton (3aR,5S,8aR,9aR)-3a, 5,6,7,8,8a,9,9a-oktahidro-5,8adimetil-3-metilen-nafto[2,3-b]furan-2(3H)-on (1), izoalantolakton (2) i oksialantolakton (3)

Fig. 18 - (+)-Alantolactone $\quad(3 \mathrm{a} R, 5 \mathrm{~S}, 8 \mathrm{a} R, 9 \mathrm{a} R)-3 \mathrm{a}, 5,6,7,8,8 \mathrm{a}, 9,9 \mathrm{a}-\mathrm{octahydro-}$ 5,8a-dimethyl-3-methylene-naphto[2,3-b]furan-2(3H)-one (1), isoalantolactone (2) and oxyalantolactone (3)

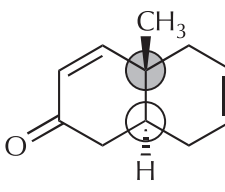

$(-)$-trans-dekalon (-)-trans-decalone

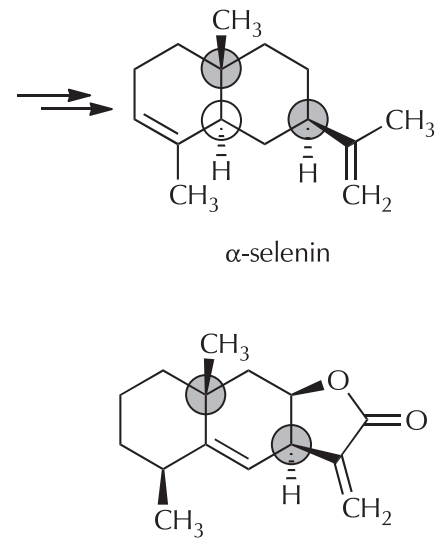

alantolakton 1

alantolactone 1

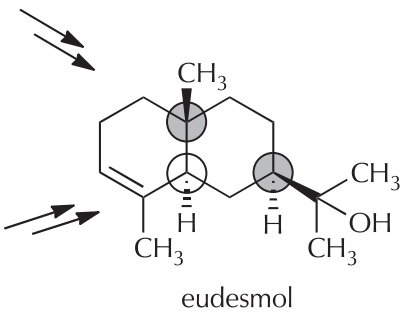

Shema 2 - Korelacija apsolutne konfiguracije na C(8a) i C(3a) atomima alantolaktona $1 \mathrm{~s}$ poznatom strukturom (-)- trans-dekalona preko $\alpha$-selenina i eudesmola ${ }^{17}$

Scheme 2 - Correlation of the absolute configuration on $\mathrm{C}(8 \mathrm{a})$ and $\mathrm{C}(3 \mathrm{a})$ atoms of alantolactone $\mathbf{1}$ with known structure of (-)- trans-decalone over $\alpha$-selenine and eudesmole ${ }^{17}$ 
Nešto kasnije Tanabe i suradnici pokazali su da je laktonski prsten linearno, a ne angularno vezan na dekalinski kostur, ${ }^{19,20}$ odn. da se skupina $\mathrm{OH}$ nalazi na $\mathrm{C}(9 \mathrm{a})$ a ne na atomu C(4) prema IUPAC-ovoj numeraciji. Isti autori su alantolakton preveli nizom reakcija u dihidroeudesmol poznate apsolutne konfiguracije čime je potvrđena $(R)$-apsolutna konfiguracija na C(8a) i C(3a) kiralnim centrima, ali i utvrđena (S)-konfiguracija na atomu C(5) (shema 3). ${ }^{19}$

Kada je određena $\beta$-relativna konfiguracija $C(5)$ metilne skupine $\mathrm{u}$ alantolaktonu, bilo je to neočekivano jer se tada nalazi u aksijalnom, dakle stereokemijski nepovoljnijem položaju na cikloheksanskom prstenu. ${ }^{21,22}$ Koju godinu poslije češki autori su potvrdili kemijskom korelacijom strukture tetrahidroalantolaktona s kostolom, za koji je bilo poznato da posjeduje apsolutne konfiguracije $3 \mathrm{a} R$, $4 \mathrm{aS}$ i $8 \mathrm{a} R$ na kiralnim centrima (shema 4). ${ }^{23}$

Cocker i sur. proveli su kemijsku korelaciju tetrahidronalantolaktona sa f-santoninom (shema 5). ${ }^{24}$
U toj je sintezi realizirana zanimljiva migracija laktonske skupine iz angularnog u linearni položaj na dekalinskom prstenu. Zatim treba uočiti da polazni lakton posjeduje trans-konfiguraciju, dok je za tetrahidroalantolakton cis-konfiguracija tek pretpostavljena. Tako je ostalo otvoreno pitanje je li laktonski prsten u alantolaktonu i dihidroalantolaktonu vezan cis- ili trans- na dekalin. Drugim riječima ostala je nerazjašnjena apsolutna konfiguracija na atomu C(9a). U tu svrhu primijenjena je jedna tada moderna kiroptička metoda. Ona se zasniva na spektroskopskom podatku; predznaku krivulje optičke rotacijske disperzije (ORD), kojem doprinosi laktonski centar prema HudsonKlyne-ovom pravilu. ${ }^{25}$

Prema navedenom pravilu, ako vodikov atom u $\gamma$-laktonu s kiralnim centrom na C-atomu koji nosi aciliranu hidroksilnu supinu (alkoksi ugljikov atom) leži ispod ravnine crteža u prikazanoj projekciji na slici 19, tada je taj lakton dekstrorotatoran, odn. pokazuje pozitivnu ORD-krivulju, i<smiles>C=C1C(=O)O[C@H]2C[C@]3(C)CCCC(C)C3=C[C@H]12</smiles><smiles>CC(CO)C1=CC[C@]2(C)CCC[C@H](C)C2C1</smiles><smiles>CC(C)C</smiles><smiles>CC(=O)C1CC[C@@]2(C)CCC[C@H](C)C2C1</smiles>

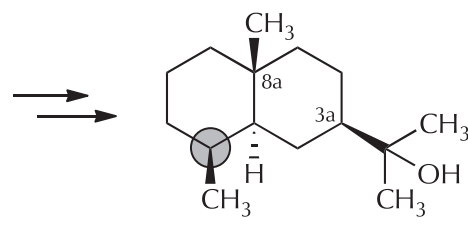

dihidroeudesmol dihydroeudesmole

Shema 3 - Kemijska korelacija alantolaktona i dihidroeudesmola ${ }^{19}$ Scheme 3 - Chemical correlation of alantolactone with dihydroeudesmole ${ }^{19}$

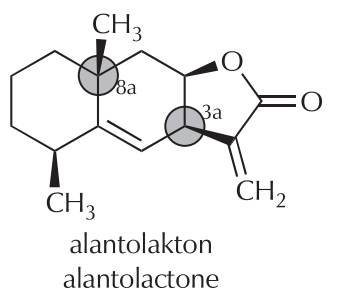

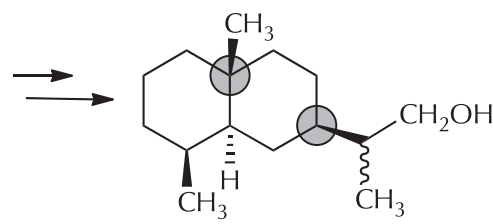

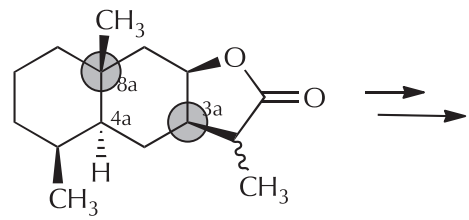

tetrahidroalantolakton tetrahydroalantolactone

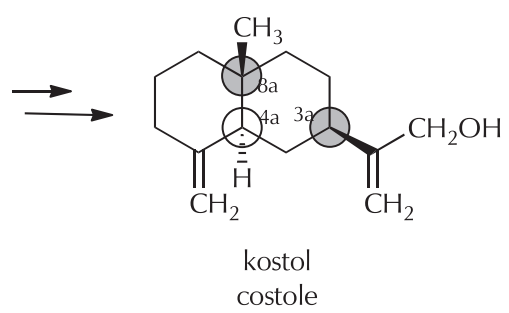

Shema 4 - Kemijska korelacija(+)-alantolaktona i kostola ${ }^{23}$

Scheme 4 - Chemical correlation of alantolactone with costole ${ }^{23}$ 


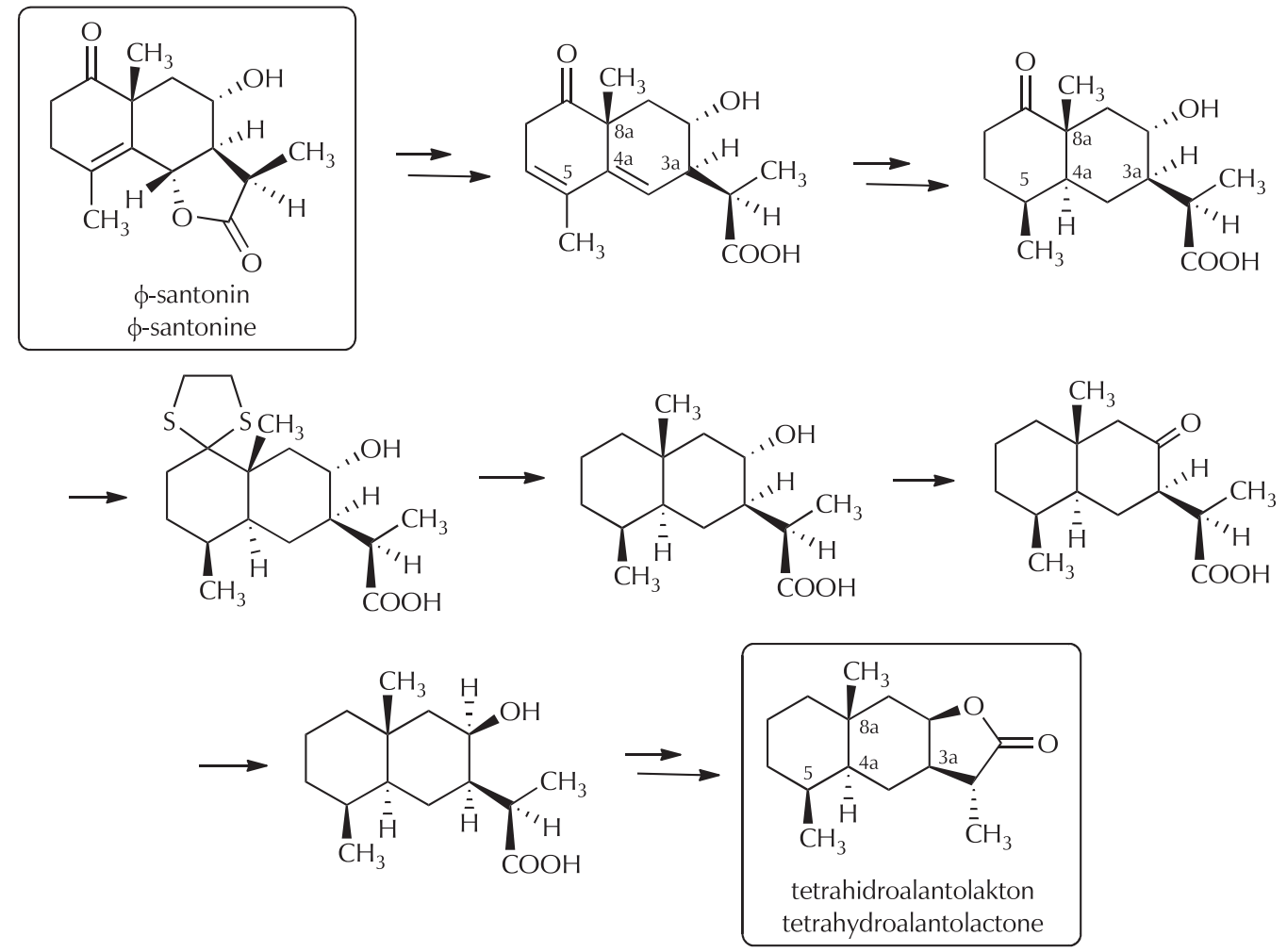

Shema 5 - Kemijska korelacija tetrahidroalantolaktona i f-santonina ${ }^{24}$

Scheme 5 - Chemical correlation of tetrahydroalantolactone and f-santonine ${ }^{24}$

obrnuto. Na slici 19 rotirana je formula eudesmana $\mathbf{A}$ tako da se jasno vidi $\alpha$-H-atom na alkoksi C-atomu. ${ }^{27} \mathrm{Na}$ istoj slici pokazana je projekcija laktonske skupine seskviterepenskih laktona, eudesmana A i B, koji posjeduju suprotne apsolutne konfiguracije na alkoksilnom ugljikovu atomu. ${ }^{26,27}$
Na slici 20 vidimo da je ORD-krivulja za eudesman A pozitivna u skladu s navedenim pravilom te iz strukturne formule slijedi $(R)$-konfiguracija na alkoksi C-atomu. Negativna krivulja za strukturni izomer B ukazuje na (S)-konfiguraciju na analognom kiralnom centru.<smiles>CC1CC(=O)O[C@@H]1C</smiles>

( ORD

seskviterpenski laktoni sesquiterpene lactones

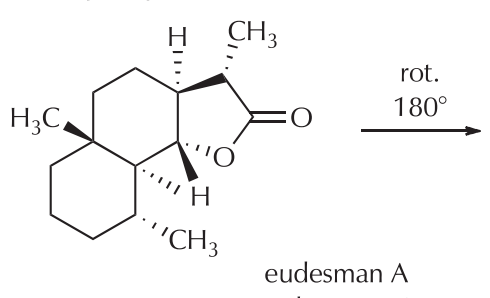
eudesmane $\mathrm{A}$

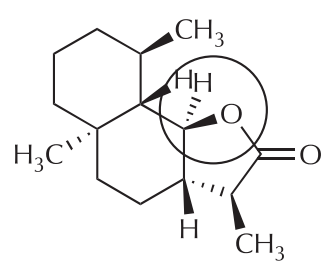

$$
\mathrm{CH}_{3}
$$<smiles>C[C@H]1OC(=O)CC1(C)C</smiles>

$\mathrm{H}$

ORD

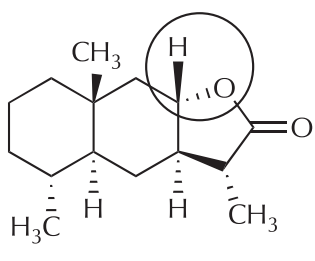

eudesman B eudesmane $B$

Slika 19 - Enantiomerne konfiguracije g-laktona i suprotni predznaci pripadnih ORD-krivulja; prikaz eudesmana A i B suprotnih konfiguracija na alkoksilnom C-atomu

Fig. 19 - Enantiomeric configurations of g-lactones and opposite signs of their ORD curves; presentation of eudesmanes $\mathrm{A}$ and $\mathrm{B}$ with opposite configurations on the alcoxy $\mathrm{C}$-atom 


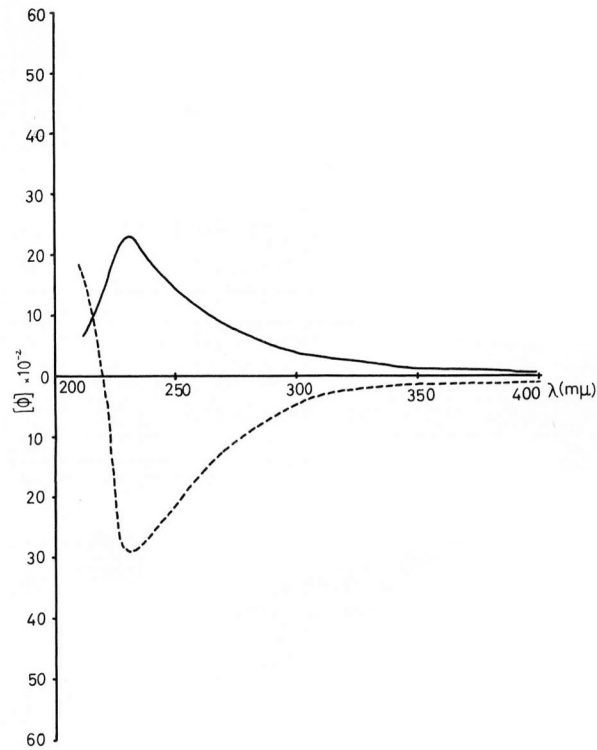

Slika 20 - ORD krivulje eudesmana A $(-)$ i B $(----)^{26}$

Fig. 20 - ORD curves of eudesmane $\mathbf{A}(-)$ and $\mathbf{B}(---)^{26}$

Tetrahydroalantolactone $(\mathrm{X})$, although of general type (IX), shows a plain negative o.r.d. curve at low wavelength. This lactone and similar related compounds are now being investigated in collaboration with Professor W. Cocker (Trinity College, Dublin).

Slika 21 - Izvadak iz rada citiranog u ref. 25

Fig. 21 - Excerpt from the paper cited in ref. 25

Iznenađenje se javilo pri pokušaju određivanja tom metodom apsolutne konfiguracije na C(9a) u tetrahidroalantolaktonu! $U$ originalnom radu autori navode kako citiramo (slika 21). ${ }^{25}$

Dakle tetrahidroalantolakton je iznenađujuće odstupio od Hudson-Klyneova pravila i pokazao negativnu ORD-krivulju umjesto očekivane pozitivne, tj. izostala je potvrda $(R)$-konfiguracije na C(9a). Autori su najavili rješenje tog problema, ali ga nisam našao objavljenog. Kasnije su međutim u više navrata drugi autori pokazali da se javljaju iznimke od "laktonskog pravila" kada na predznak ORD-krivulje utječu drugi kiralni centri u molekuli koji se nalaze u blizini stereoelektronskog okoliša kiralnog centra laktonske skupine.

No svi rezultati objavljeni u literaturi ipak konvergiraju prema definiciji apsolutne konfiguracije na četiri kiralna centra u alantolaktonu kao $3 \mathrm{a} R, 5 S, 8 \mathrm{a} R, 9 \mathrm{a} R$, kao što je pokazano u formuli 1 na str. 18.

Godine 1986. provedena je prva rendgenska strukturna analiza uzorka prirodnog (+)-alantolaktona te struktura molekule prikazana na slici $22 .^{28}$

$U$ slici se ne primjenjuje IUPAC-ova numeracija, ali struktura jasno pokazuje $\beta$-položaj metilnih skupina na C-atomima ovdje označenim C(4) i C(10) i cis-fuzionirani 5-eročlani laktonski prsten u konformaciji planarizirane omotnice (engl. flattened envelope). Posebno je značajna

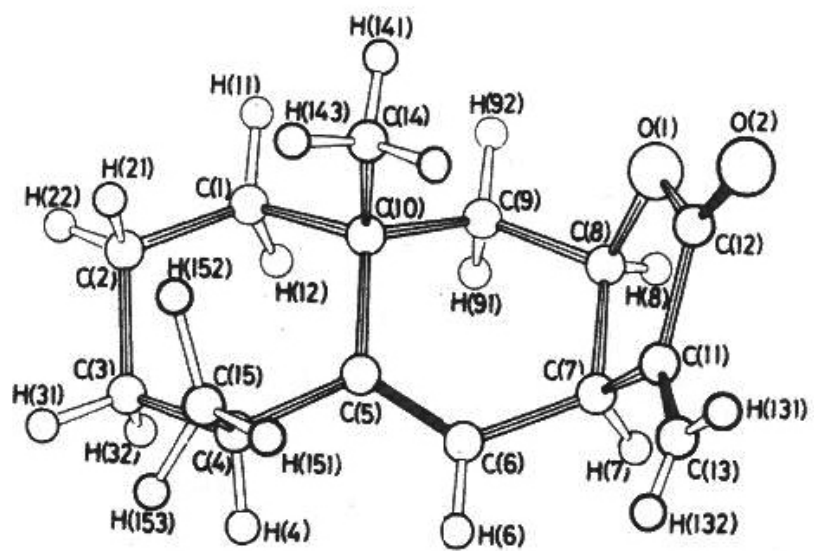

Slika 22 - Kristalna struktura (+)-alantolaktona ${ }^{28}$ Fig. 22 - Crystal structure of (+)-alantolactone ${ }^{28}$

izloženost reaktivne $\alpha$-metilenske skupine laktona koja je skoro u okomitom položaju prema bicikličkom kosturu. Kako ćemo vidjeti, toj strukturnoj značajki kao i reaktivnosti enona pripisan je bitan doprinos biološkim djelovanjima, posebno antitumornom, alantolaktona i nizu drugih $\alpha$-metilen- $\gamma$-laktona.

Konfiguracije na kiralnim centrima u strukturi na slici 22 odgovaraju onima u formuli 1 . No valja ipak istaknuti da u 
tom radu nije određena apsolutna konfiguracija (+)-enantiomera alantolaktana $\mathbf{1}$ prikazana na slici 22, nego je izvedena iz prethodnih kemijskih korelacija koje se ovom poglavlju analiziraju. Naime, određivanje apsolutne konfiguracije rendgenskom strukturnom analizom zahtijeva primjenu Bijvoetove metode anomalne disperzije (engl. anomalous disperson, ili resonant scattering), koju autor $u$ ovom radu nije primijenio. ${ }^{29}$ Prema pretraživanju baze podataka CSD-a verzija 5.37, do studenoga 2015. određeno je 12 kristalnih struktura alantolaktona, izolanolaktona, njihovih epoksida i još nekoliko derivata.*

I tako se pokazuje da se predložena apsolutna konfiguracija alantolaktona zasniva na kemijskoj i spektroskopskoj korelaciji sa sličnim strukturama, od kojih ova zadnja nije jednoznačna. Ipak možemo sa sigurnošću reći da je struktura (+)-alantolaktona 1 potpuno u skladu s današnjim znanjima o građi brojnih sličnih terpena i seskviterpena.

* Zahvaljujem kolegama dr. sc. Mariji Luić i dr. sc. Zoranu Štefaniću s Instituta Ruđer Bošković za provedeno pretraživanje i pripremljene podatke.

\section{Sinteze racemata alantolaktona i izoalantolaktona}

Radovi na utvrđivanju strukture alantolaktona i prvi rezultati bioloških istraživanja koja su ukazivala na niz potencijalnih terapeutskih svojstava potaknuli su totalne sinteze tih spojeva. Prvom stereoselektivnom sintezom pripravljen je racemat alantolaktona ( \pm )-1 polazeći od lako dostupnog Hagemannova estera 4. Budući da alantolakton posjeduje 4 kiralna centra, mogući broj stereoizomera je $2^{4}$ odn. 16. Tom sintezom priređen je jedan od osam mogućih racemata (shema 6). ${ }^{30}$

U shemi su prikazane apsolutne konfiguracije kao i u originalnom radu, koje odgovaraju onima u prirodnom (+)-alantolaktonu iako u to vrijeme one nisu bile jednoznačno potvrđene. Struktura pripravljenog racemata potvrđena je poredbom s IR i ${ }^{1} \mathrm{H}-\mathrm{NMR}$-spektrima prirodnog (+)-alantolaktona te retencijskim vremenom u plinskoj kromatografiji. Ključne korake u toj sintezi predstavljaju c), konstrukcija karbocikličkog kostura olefinskom ciklizacijom 6 u 7, g) modifikacija ugljikovog skeleta stereoselek-<smiles>C=CCCC1=C(C)CC[C@H](CC)C1(O)CCC=C</smiles>

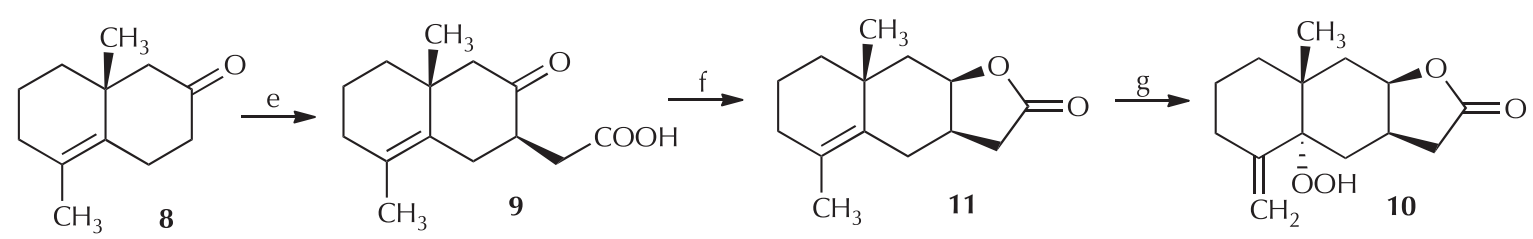<smiles>C[C@H]1CCC[C@]2(C)C[C@H]3OC(=O)C[C@@H]3C[C@]12O</smiles><smiles>C[C@H]1C[C@H](I)CC[C@]1(C)C[C@@H]1OC(=O)C[C@H]1C</smiles><smiles>COC(=O)C1=C(O[Na])O[C@@H]2C[C@@]3(C)CCC[C@H](C)C3=C[C@H]12</smiles><smiles>C=C(CO)C1C=C2[C@@H](C)CCC[C@]2(C)C[C@H]1O</smiles><smiles>C=C1C(=O)O[C@@H]2C[C@@]3(C)CC[C@H](I)[C@H](C)C3=C[C@H]12</smiles>

Shema 6 - Prva totalna sinteza racemičnog alantolaktona. ${ }^{30}$

Reakcijski uvjeti i reagensi: a) NaH/4-brombut-1-en, zatim $15 \% \mathrm{KOH} / \mathrm{EtOH} / \Delta$, b) $\left.\mathrm{MeLi} / \mathrm{Et}_{2} \mathrm{O}, \mathrm{c}\right) \mathrm{HCO}$ $\mathrm{OH} / \Delta$, d) $\mathrm{H}_{2} \mathrm{CrO}_{4} / \mathrm{MeOH}$, e) pirolidin, $\left.\left.\mathrm{BrCH}_{2} \mathrm{COOEt} / \mathrm{KOH}, \mathrm{f}\right) \mathrm{CH}_{2} \mathrm{~N}_{2} / \mathrm{Et}_{2} \mathrm{O}, \mathrm{KBH}_{4} / \mathrm{MeOH}, \mathrm{g}\right) h v, \mathrm{O}_{2} / \mathrm{Et}_{2} \mathrm{O}$, h) $\mathrm{Pd} / \mathrm{C}, \mathrm{H}_{2}$, i) $\mathrm{SOCl}_{2} /$ piridin, j) $\mathrm{NaH} / \mathrm{C}=\mathrm{O}(\mathrm{OMe})_{2}$, k) $\left.\mathrm{LiAlH}_{4} / \mathrm{Et}_{2} \mathrm{O}, \mathrm{I}\right) \mathrm{MnO}_{2} /$ benze

Scheme 6 - First total synthesis of racemic alantolactone ${ }^{30}$

The reaction conditions and reagents: a) $\mathrm{NaH} / 4$-bromobut-1-ene, then $15 \% \mathrm{KOH} / \mathrm{EtOH} / \Delta$, b) MeLi/ $\mathrm{Et}_{2} \mathrm{O}$, c) $\mathrm{HCOOH} / \Delta$, d) $\mathrm{H}_{2} \mathrm{CrO}_{4} / \mathrm{MeOH}$, e) pyrrolidine, $\mathrm{BrCH}_{2} \mathrm{COOEt} / \mathrm{KOH}$, f) $\mathrm{CH}_{2} \mathrm{~N}_{2} / \mathrm{Et}_{2} \mathrm{O}, \mathrm{KBH}_{4} / \mathrm{MeOH}$, g) $\left.h v, \mathrm{O}_{2} / \mathrm{Et}_{2} \mathrm{O}, \mathrm{h}\right) \mathrm{Pd} / \mathrm{C}, \mathrm{H}_{2}$, i) $\mathrm{SOCl}_{2} /$ pyridine, j) $\mathrm{NaH} /\left(\mathrm{C}=\mathrm{O}(\mathrm{MeO})_{2}, \mathrm{k}\right) \mathrm{LiAlH}_{4} / \mathrm{Et}_{2} \mathrm{O}$, I) $\mathrm{MnO}_{2} /$ benzene 
<smiles>COc1ccc2c(c1)CCCC2=O</smiles>

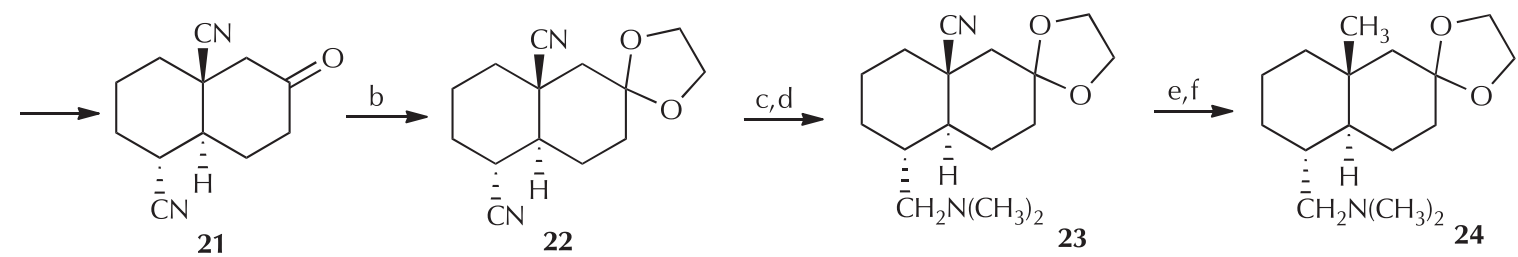<smiles></smiles><smiles>C=C1CCC[C@]2(C)CC(=O)CC[C@H]12</smiles><smiles>C=C1CCC[C@]2(C)CC(=O)[C@H](CC(=O)OCC)C[C@@H]12</smiles><smiles>C=C1C[C@H](C)C[C@@]2(C)C[C@H]3OC(=O)C[C@H]3C[C@H]12</smiles><smiles>C=C1CC[C@@]2(C)C[C@H]3OC(=O)C(CO)[C@H]3CC12</smiles><smiles>C=C1CCC[C@@]2(C)C[C@H]3OC(=O)C(=C)[C@H]3CC12</smiles>

( \pm )-izoalantolakton 2

( \pm )-isoalantolactone 2

Shema 7 - Prva sinteza sinteza $( \pm)$-izoalantolaktona ${ }^{31}$

Reakcijski uvjeti i reagensi: a) $\mathrm{AlEt}_{3}, \mathrm{HCN}$, b) $\mathrm{HOCH}_{2} \mathrm{CH}_{2} \mathrm{OH}, \mathrm{H}+/ \Delta$, c) $\mathrm{Pd}, \mathrm{H}_{2}$, d) $\mathrm{HCHO}, \mathrm{NaBH}_{4}$, e) $\mathrm{Al}(\mathrm{Bu})_{2} \mathrm{H}$, f) $85 \% \mathrm{NH}_{2} \mathrm{NH}_{2}, \mathrm{H}_{2} \mathrm{O}, \mathrm{KOH} /$ glikol $/ \Delta$, g) MCPBA $/ \Delta$, h) $80 \% \mathrm{AcOH} / \Delta$, i) pirolidin $/ \Delta$ j) $\mathrm{CH}_{2} \mathrm{Br}-$ COOEt, k) $\mathrm{NaBH}_{4} / \mathrm{MeOH}$, I) $\left.\left.\mathrm{HCOOEt}, \mathrm{NaH}, \mathrm{m}\right) \mathrm{NaBH}_{4} / \mathrm{MeOH}, \mathrm{n}\right) \mathrm{TsCl} /$ piridin $/ \Delta$

Scheme 7 - First synthesis of $( \pm)$-isoalantolactone ${ }^{31}$

The reaction conditions and reagents: a) $\mathrm{AlEt}_{3}, \mathrm{HCN}$, b) $\mathrm{HOCH}_{2} \mathrm{CH}_{2} \mathrm{OH}, \mathrm{H}+/ \Delta$, c) $\mathrm{Pd}, \mathrm{H}_{2}$, d) $\mathrm{HCHO}$, $\mathrm{NaBH}_{4}$, e) $\mathrm{Al}(\mathrm{Bu})_{2} \mathrm{H}$, f) $85 \% \mathrm{NH}_{2} \mathrm{NH}_{2}, \mathrm{H}_{2} \mathrm{O}, \mathrm{KOH} /$ glycol$/ \Delta$, g) MCPBA/ $\Delta$, h) $80 \% \mathrm{AcOH} / \Delta$, i) pyrrolidine $/ \Delta$ j) $\mathrm{CH}_{2} \mathrm{BrCOOEt}, \mathrm{k}$ ) $\mathrm{NaBH}_{4} / \mathrm{MeOH}$, I) $\left.\left.\mathrm{HCOOEt}, \mathrm{NaH}, \mathrm{m}\right) \mathrm{NaBH}_{4} / \mathrm{MeOH}, \mathrm{n}\right) \mathrm{TsCl} /$ pyridine/ $\Delta$

tivnom fotooksigenacijom olefina $\mathbf{1 0}$ zatim i) dehidratacija 12 u 13, te stupnjevi j,k,l) koji predstavljaju originalnu sintezu $\alpha$-metilen- $\gamma$-butirolaktona u transformaciji 13 u (土)-1. I tako je racemični alantolakton pripravljen u 12 sintetskih koraka, što ovu elegantnu sintezu ne čini prihvatljivom za izvedbu u tehnološkom mjerilu.

Budući da su farmakološka istraživanja u posljednjim desetljećima sve više ukazivala na značajna i različita farmakoforna svojstva $\gamma$-butirolaktonske skupine, to su mnogi prirodni spojevi koji sadrže ovu skupinu postali predmet intenzivnih sintetskih istraživanja, među njima i izoalantolakton 2. Objavljene su dvije stereoslektivne totalne sinteze racemičnog izoalantolaktona $( \pm)-2 .{ }^{31-33}$

Prva sinteza izoalantolaktona prikazana je u shemi $7.31,32$ Pošavši od metoksi- $\alpha$-naftola 16, autori su pripravili ciklički keton 17, zatim konjugirani dienon 18 te adicijom jednog mola HCN dobili smjesu cis/trans-dijastereomera 19/20. S drugim molom cijanida dobiven je, kako navode, "samo jedan dicijanoketon", zapravo trans-racemat 21. Nakon zaštite keto-skupine u $\mathbf{2 2}$ preveli su selektivnim reduktivnim metiliranjem jednu cijano-skupinu u dimetilaminome- tilnu skupinu u spoju 23, zatim hidrogenolizom druge cijano-skupine u premoštenju pripravili spoj 24. U dva koraka je terc-amino skupina preko $\mathrm{N}$-oksida $\mathbf{2 5}$ prevedena u metilensku skupinu u 26. Alkilacija intermedijarnog enamina po Storku ${ }^{34}$ (nije prikazan u shemi) rezultirala je spojem 27 s kaboksimetlnom skupinom u $\beta$-položaju. Ciklizacija u lakton 28 uslijedila je nakon redukcije karbonilne skupine koja je protekla nestereoselektivno, kako je ukazano u radu Marshalla i sur..$^{30}$ Za lakton $\mathbf{2 8}$ navedena je cis-konfiguracija iako je vjerojatno nastala smjesa cis/trans-izomera. U zadnjim koracima uvedena je egzo-metilenska skupina u $\gamma$-lakton preko intermedijara 29. Ne navode se iskorištenja u pojedinom koraku niti ukupno iskorištenje na (土)-izoalantolaktonu 2 nakon 16 sintetskih koraka.

Druga, znatno kraća sinteza prikazana je u shemi $8 .^{33}$ Polazeći od enona 30 autori su pripravili intermedijar 32 modificirajući uvjete iz ranijeg rada ${ }^{32}$ te zatim uveli karboksimetilnu skupinu u dva koraka, aktivirajući $\alpha$-C atom prolaznim uvođenjem metoksikarbonilne skupine u spoj $\mathbf{3 4}$ u koraku f) koristeći dimetilkarbonat. $U$ shemi 8 upotrijebljen je broj 28 za intermedijar već pripravljen u shemi 7 . 
Ključni stereoselektivni korak te sinteze od samo osam koraka postignut je pripravom cis-laktona. Upotrebom K-selektrida, kalijeve soli sterički zahtjevnog borhidrida, isklju-
Čivo je nastao cis-laktonski prsten u spoju 28 (shema 9). U shemi je istaknuto snažno steričko ometanje aksijalne metilne skupine pristupu K-selektrida koji bi vodio do ne-<smiles>C=C1CCC[C@]2(C)CC(=O)CC[C@H]1C2=O</smiles><smiles>C=C1CCC[C@]2(C)CC(=O)[C@H](CC(=O)O)C[C@H]1C2=C</smiles><smiles>C=C1CCC[C@@]2(C)C[C@H]3OC(=O)C(C)(C(=O)OC)[C@H]3C[C@H]12</smiles><smiles>C=C1CCC[C@]2(C)C[C@@H]3OC(=O)C(=C)[C@H]3CC12</smiles>

( \pm )-izoalantolakton 2

(土)-isoalantolactone 2

Shema 8 - Druga totalna sinteza ( \pm )-izoalantolaktona $\mathbf{2}^{33}$

Reakcijski uvjeti i reagensi: a) $\mathrm{Li}\left(\mathrm{CH}_{3}\right)_{2} \mathrm{Cu}, \mathrm{Et}_{2} \mathrm{O}$, b) $\left.\mathrm{Ph}_{3} \mathrm{P}^{+}-\mathrm{CH}_{2}{ }^{-}, \mathrm{DMSO}, \mathrm{c}\right) \mathrm{NaH}, \mathrm{CO}\left(\mathrm{OCH}_{3}\right)_{2}$, d) $\mathrm{NaH}$, $\mathrm{BrCH}_{2} \mathrm{COOCH}_{3}, \mathrm{THF}$, zatim Ba(OH) $)_{2}, \mathrm{EtOH} / \Delta$, e) $\mathrm{CH}_{2} \mathrm{~N}_{2}, \mathrm{Et}_{2} \mathrm{O}$, zatim K-selektrid, $\mathrm{THF},-78^{\circ} \mathrm{C}$, f) $\mathrm{NaH}$, $\mathrm{CO}\left(\mathrm{OCH}_{3}\right)_{2}$, g) $\mathrm{CH}_{2} \mathrm{O}(37 \%), \mathrm{Me}_{2} \mathrm{NH} \cdot \mathrm{HCl}$, dioksan, h) Mel, DMF, $80{ }^{\circ} \mathrm{C}$

Scheme 8 - Second total synthesis of $\left( \pm\right.$ )-isoalantolactone $\mathbf{2}^{33}$

The reaction conditions and reagents: a) $\mathrm{Li}\left(\mathrm{CH}_{3}\right)_{2} \mathrm{Cu}, \mathrm{Et}_{2} \mathrm{O}$, b) $\left.\mathrm{Ph}_{3} \mathrm{P}^{+}-\mathrm{CH}_{2}{ }^{-}, \mathrm{DMSO}, \mathrm{c}\right) \mathrm{NaH}, \mathrm{CO}(\mathrm{O}-$ $\left.\mathrm{CH}_{3}\right)_{2}$, d) $\mathrm{NaH}, \mathrm{BrCH}_{2} \mathrm{COOCH}_{3}, \mathrm{THF}$, then $\mathrm{Ba}(\mathrm{OH})_{2}, \mathrm{EtOH} / \Delta$, e) $\mathrm{CH}_{2} \mathrm{~N}_{2}, \mathrm{Et}_{2} \mathrm{O}$, then K-selectride, THF, $-78{ }^{\circ} \mathrm{C}$, f) $\mathrm{NaH}, \mathrm{CO}\left(\mathrm{OCH}_{3}\right)_{2}$, g) $\mathrm{CH}_{2} \mathrm{O}(37 \%), \mathrm{Me}_{2} \mathrm{NH} \cdot \mathrm{HCl}$, dioxane, h) Mel, DMF, $80{ }^{\circ} \mathrm{C}$<smiles>C=C1CCC[C@]2(C)CC(=O)[C@H](CC(=O)O)C[C@H]1C2=C</smiles>
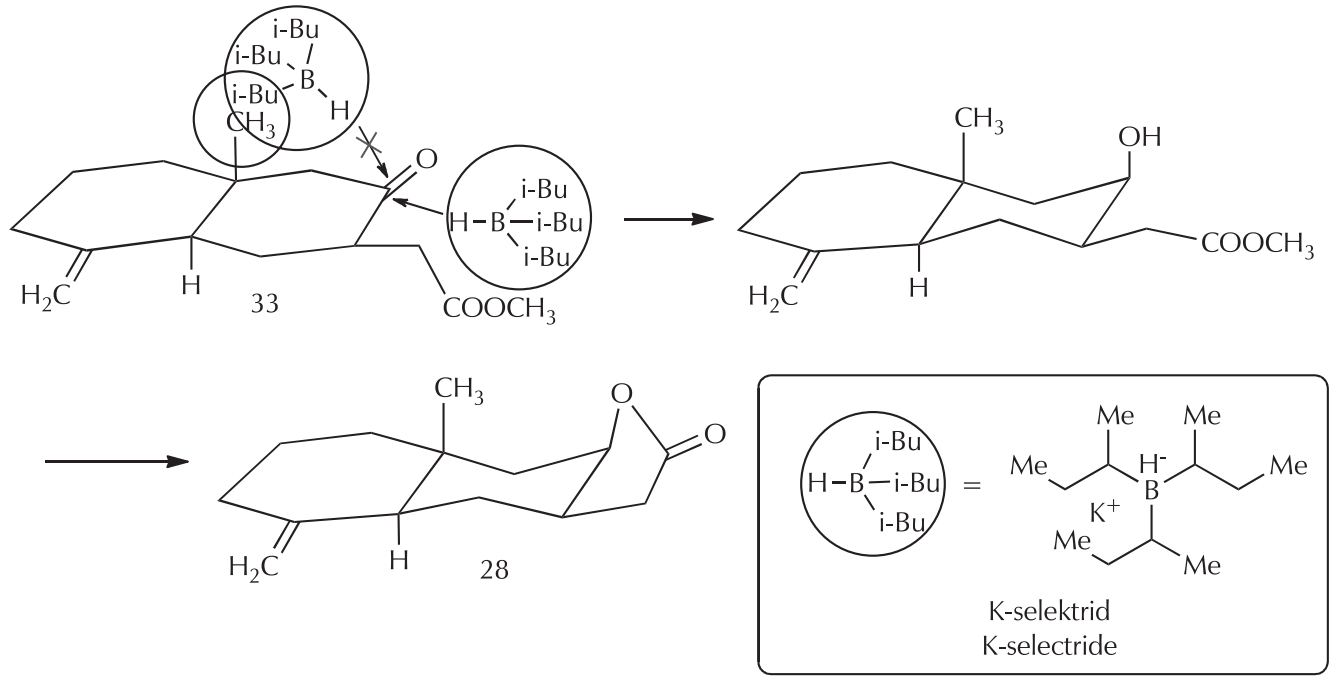

Shema 9 - Stereoselektivna redukcija ketona i ciklizacija u cis-lakton 13

Scheme 9 - Stereoselective reduction of ketone and cyclization to cis-lactone $\mathbf{1 3}$ 
poželjnog trans-laktona s $\mathrm{OH}$-skupinom u ekvatorijalnom položaju. Postignuta cis-selektivnost iznosila je preko $98 \%$ dok s nizom drugih kompleksnih hidrida nije prelazila $60 \%$.

Ostali koraci u shemi 8 idu uz zadržavanje konfiguracije na sva četiri kiralna centra. Vrijedno je istaknuti aktivaciju $\alpha-C$ atoma do keto-skupine, tj. povećanje $\mathrm{C}-\mathrm{H}$-kiselosti prolaznim uvođenjem karboksimetilne skupine koristeći dimetilkarbonat i zatim provedbu Mannichove reakcije. U zadnjim koracima eliminacija terc-amina u intermedijaru 35 vodi do egzo-metilenske skupine u ( \pm )-izoalantolaktonu $\mathbf{2}$.

Do sada u literaturi nije opisana asimetrična sinteza enantiomerno (optički) čistog alantolaktona 1 niti izoalantolaktona 1a. Taj projekt sigurno predstavlja kako znanstveni tako i tehnološko-ekonomski vrlo vrijedan izazov s obzirom na visoku cijenu prirodnog materijala i zanimljive rezultate brojnih bioloških istraživanja, od kojih su najznačajnija navedena u sljedećem poglavlju. Neki podatci o cijeni, globalnom tržištu i patentnoj zaštiti navedeni su u zadnjem poglavlju.

\section{Terapeutske perspektive alantolaktona - je li to čudotvoran lijek?}

Impresivan je broj u posljednje vrijeme zapaženih, terapeutski obećavajućih bioloških svojstava alantolaktona i izoalantolaktona. Ona potvrđuju i proširuju tradicionalna zapažanja o ljekovitom učinku ekstrakta iz korijena Inula helenium i drugih vrsta Inula. Predklinička istraživanja provode se kako s pročišćenim aktivnim spojevima iz korijena vrsta Inula tako i s ekstrahiranim smjesama. Tako je hlapljivo ulje Inula helenium uz antitumorsko pokazalo i antibakterijsko djelovanje. ${ }^{35}$ Zapaženo zanimljivo djelovanje alantolaktona kojim reducira sklonost kukaca prema hrani (engl. insect feeding deterrent) te ukazano na mogućnost zaštite biljaka od napada određenih skupina kukaca. ${ }^{36} \mathrm{U}$ više radova potvrđeno je njegovo insekticidno i antibakterijsko djelovanje. ${ }^{37,38}$ Među antibakterijskim svojstvima eudesmanolida iz Inula helenium posebno se ističe aktivnost alantlaktona prema Mycobacterium tuberculosis. ${ }^{39}$

Za alantolakton i niz analoga izoliranih iz korijena Inula helenium L. određena je antimikrobna aktivnost na nizu bakterijskih sojeva. Nekoliko derivata pokazalo je snažno antibakterijsko djelovanje, znatno veće od poznatog antibiotika ampicilina.$^{40}$ Alantolakton i izoalantolakton pokazali su najdjelotvornije insekticidno djelovanje u nizu testiranih seskviterpenoida, flavanoida, fitosterola i nekih drugih prirodnih spojeva, posebno na ličinku Aedes aegypti. U nastavku istraživanja provedene su kemijske modifikacije alantolaktona radi povećanja insekticidnog djelovanja, a najbolji rezultat dao je derivat alantolaktona priređen $\mathrm{Mi}$ - chaleovom adicijom propilamina na $\alpha$-metilensku skupinu. ${ }^{41}$ Cantrell $i$ sur. pokazali su u nizu radova da alantolakton spada u najdjelotvornije pesticide te da uz to posjeduje i antimikobakterijska svojstva. ${ }^{42,43}$

Pokazano je da alantolakton sprječava ekspresiju oksidaze dušikova oksida i ciklooksigenaze, ključnih enzima u pojavi inflamatornih procesa, te stoga pokazuje obećavajuće antiinflamatorno djelovanje. ${ }^{37}$ Sve više se istražuje mehanizam antitumorskog djelovanja alantolaktona. Nedavno je opisano da alantolakton inducira apoptozu u glioblastiloma stanicama i definiran je mehanizam indukcije. Taj rezultat obećava primjenu alantolaktona u terapiji glioblastiloma multiform, najmalignijeg i najagresivnijeg primarnog tumora mozga u odraslih. ${ }^{44}$ Pošavši od alantolaktona i izolantolaktona pripremljen je niz citotoksičnih $\alpha$-aminometil-supstituiranih laktona stereoselektivnom Michaelovom adicijom sekundarnih amina, shema 10 . Svi novi spojevi inducirali su apoptozu i djelovali kao alkilirajući agensi. ${ }^{44}$ Zanimljivo je primijetiti da Michaelovi adukti zapravo predstavljaju potencijalnu zaštitnu skupinu za $\alpha$-metilensku dvostruku vezu u laktonu budući da se aminoskupina može eliminirati nakon kvaternizacije, što je prikazano u shemi 8.
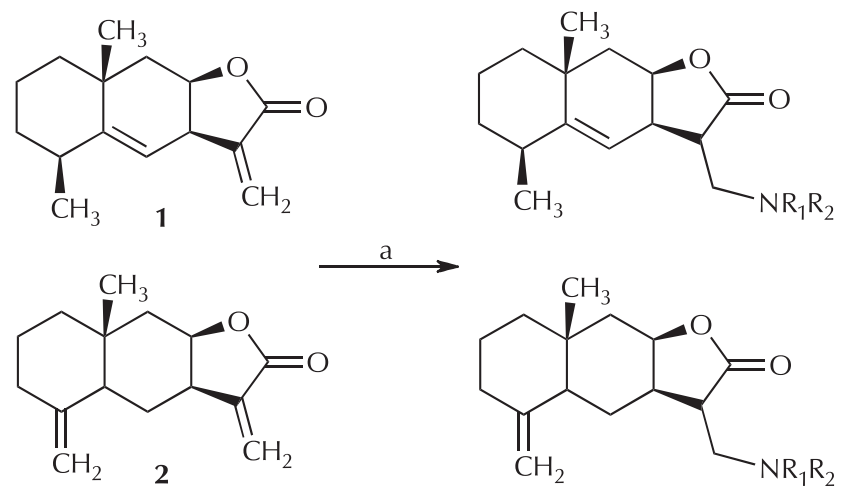

a) $\mathrm{R}_{1} \mathrm{R}_{2} \mathrm{NH}$, EtOH, $0^{\circ} \mathrm{C}$, preko noći $\mathrm{R}_{1} \mathrm{R}_{2} \mathrm{NH}, \mathrm{EtOH}, 0^{\circ} \mathrm{C}$, overnight

Shema 10 - Priprava citotoksičnih produkata Michaelovom adicijom na alantolakton i izoalantolakton ${ }^{44}$

Scheme 10 - Preparation of cytotoxic products by Michael-type addition to alantolactone and isoalantolactone ${ }^{44}$

Za smjesu alantolaktona i izoalantolaktona izoliranu iz korijena Inula helenium subsp. turcoracemosa utvrđeno je snažno antiproliferativno $\mathrm{i}$ antimikrobno djelovanje. ${ }^{40}$ Testiranjem na antitumorsko djelovanje od sedam pročišćenih seskviterpena iz korijena Inula helenium L. najaktivnijim se pokazao alantolakton, njegovo djelovanje in vitro usporedivo je s poznatim lijekom fluorouracilom. ${ }^{45}$ 


\section{Patenti, globalno tržište i cijene alantolaktona - vrijedi li danas istraživati prirodne spojeve?}

Patenti na području primjene alantolaktona i izoalantolaktona pojavljuju se posljednjih desetljeća. Odnose se ponajprije na metode izolacije i pročišćavanja aktivne supstancije nakon ekstrakcije prirodnog materijala.

Tako se u jednom patentu štiti "simultana priprava" oba laktona koja se zapravo sastoji od njihove kromatografske separacije iz ekstrakta upotrebljavajući u kontinuiranom procesu trokomponentnu smjesu $n$-heksan-etilacetat-acetonitril kao eluens. ${ }^{46}$ Zaštićena je priprava i primjena "visoko djelotvornog ekstrakta" iz Inula racemosa kojim se postiže vazodilacija i drugi učinci na krvožilni sustav. ${ }^{47}$

U 2016. objavljen je tehnološki postupak izolacije alantolaktona i izoalantolaktona iz korijena Inula racemosa Hook.f ekstrakcijom superkritičnom tekućinom uz primjenu $\mathrm{CO}_{2}$ (engl. SFE, supercritical fluid extraction). Opisani su optimalni uvjeti za ekstrakciju, tlak $50 \mathrm{MPa}$, temperatura $50{ }^{\circ} \mathrm{C}$ te izolacija produkta smrzavanjem. Na taj način obogaćen je sadržaj na oba izomera u produktu izolacije do $30,7 \%{ }^{48}$

Primjena ekstrakta Inula helenium L. ili izoliranih alantolaktona i izoalantolaktona u terapiji malignih i inflamatornih oboljenja predmet je jedne patentne zaštite. ${ }^{49}$ Patentima je posebno zaštićeno anthelminsko i antineoplastno djelovanje hlapljivih ulja koja sadrže izoalantolakton. ${ }^{50}$

Kompleksnost sinteze i ograničena dostupnost iz prirodnog materijala s jedne strane te sve veći broj objavljenih rezultata o specifičnom biološkom učinku alantolaktona s druge, čine ga danas vrlo traženim prirodnim spojem na svjetskom tržištu. To rezultira i visokom cijenom, koja je dostupna samo za neke distributere. Tako Sigma-Aldrich nudi alantolakton po cijeni od 81,10 \$/5 mg, 323,50 \$/50 mg, Molbase Co. po cijeni od $59 \$ / 10 \mathrm{mg}, 759$ \$/g, ali od nedavno nudi i racemat po cijeni od $1974 \$ / \mathrm{kg}$. Taj podatak ukazuje na to da je na većoj skali realizirana (ili planirana!?) komercijalna sinteza racemata alantolaktona.

Kao proizvođači alantolaktona reklamira se nekoliko tvrt- ki, uglavnom iz Istočne Azije; China Chemical, Chengdu Pufeide, Exion Hong Kong, Tocrise Biotech Band i dr. Podatci o cijeni alantolaktona dostupni su od tih tvrtki tek nakon potpisivanja ugovora o tajnosti i priloženim podatcima o tražitelju informacije!

Početkom 2016. g. objavljen je dokument pod imenom Alantolactone (CAS 546-43-0) Market Research Report, u kojem se nalaze podatci o globalnom tržištu, cijenama alantolaktona na lokalnim tržištima, o područjima primjene, proizvodnim postupcima i patentima. ${ }^{51}$ Taj izvještaj dostupan je po cijeni od 2500 US\$!

\section{Zaključak}

Raznovrsno biološko djelovanje spojeva dobivenih iz korijena biljke Inula helenium L. opisano je još u antička vremena, a pripravci ekstrakta korijena te biljke upotrebljavani su u narodu kao lijek protiv niza oboljenja, od dijareje, kožnih infekcija, upala dišnih organa do liječenja tuberkuloze. U drugoj polovici XIX. stoljeća utvrđeno je da je najznačajnija komponenta tih pripravka spoj nazvan helenin, inulin ili alantolakton.

Istraživanju alantolaktona i srodnih seskviterpena doprinijela su u razmaku od 40 godina dva hrvatska kemičara, Srećko Bošnjaković i nobelovac Lavoslav Ružička. Njihovi rezultati su u temelju današnjeg razvoja tih prirodnih spojeva u potencijalne lijekove na vrlo različitim terapijskim područjima. U ovom pregledu se nakon kraćeg opisa istraživanja alantolaktona i srodnih seskviterpena od strane S. Bošnjakovića i L. Ružičke iznose i noviji rezultati istraživanja strukture, sinteze i biološkog djelovanja alantolaktona i izoalantolaktona. Posebno su istaknuta terapijska područja na kojima se javlja potencijalna primjena alantolatona te prvi patenti i tržišne cijene za taj prirodni spoj.

Vrijedi još istaknuti da su u preglednom članku iz 2006. kineski autori objavili strukture 792 seskviterpena iz niza eudesmana, kamo spadaju alantolakton i njegovi srodnici te citiraju 593 rada objavljena na tom području, što jasno ukazuje velik interes raznih znanstvenih disciplina za tu skupinu prirodnih spojeva. ${ }^{52}$ 


\section{Literatura \\ References}

1. T. Bartram, Bartram's Encyclopedia of Herbal Medicine, Robinson Publishing Ltd., London, 1998.

2. M. Howard, Traditional Folk Remedies. Century, 1987., str. 135-136.

3. B.-E. van Wyk, M. Wink, Medicinal Plants of the World, Times Editions, Singapore, 2004., str. 181-182.

4. Znanstveni skup u povodu obilježavanja 150. godišnjice rođenja prof. dr. sc. Srećka Bošnjakovića, 24. 11. 2015. HAZU, Zagreb.

5. S. Bošnjaković, Gerhardtov helenin, Rad JAZU 113 (1893) 140-152.

6. C. Gerhardt, Uber das Helenin, Liebigs Ann. Chem. 34 (1840) 192-204, doi: https://doi.org/10.1002/jlac.18400340206.

7. S. Paušek-Baždar, Srećko Bošnjaković, Hrvatski biografski leksikon, sv. 2, Leksikografski zavod "Miroslav Krleža", Zagreb, 1989., str. 210.

8. S. Paušek-Baždar, Srećko Bošnjaković, u D. Grdenić (ur.), Gustav Janaček, život i djelo, HAZU, Zagreb, 2002., str. 140-141.

9. J. Kallen, Ueber Helenin und Alantcampher, Ber. Dtsch. Chem. Ges. 9 (1876) 154-157, doi: https://doi.org/10.1002/ cber.18760090148.

10. J. Bredt, Ueber das Alantolactone (Helenin), W. Posth, Liebigs Ann. Chem. 285 (1895) 349-384, doi: https://doi. org/10.1002/jlac.18952850306.

11. L. Ružička, M. M. Janot, Hoehere Terpenverbindungen. L. Zur Kentniss des Sclareols, Helv. Chim Acta 14 (1931) 645650, doi: https://doi.org/10.1002/hlca.19310140162.

12. L. Ružička, P. Pieth, Polyterpene und Polyterpenoide. LV. Zur Kentniss der alantolactone, Helv. Chim Acta 14 (1931) 10901103, doi: https://doi.org/10.1002/hlca.19310140519.

13. L. Ružička, P. Pieth, Th. Rechstein, E. Emann, Polyterpene und Polyterpenoide LXXX. Zur Kenntnis der Alantolactone. Synthese des 1,4-Dimethyl-6-isopropyl- und des 1,5-Dimethyl-7-isopropyl-naphtalins, Helv. Chim Acta 16 (1933) 268-275, doi: https://doi.org/10.1002/hlca.19330160137.

14. L. Ružička, The isoprene rule and the biogenesis of terpenic compounds. Experientia 9 (1953) 357-396, doi: https://doi. org/10.1007/BF02167631.

15. G. R. Clemo, R. D. Haworth, The constitution of santonin. Part III. Proof of the positions of the methyl groups, J. Chem. Soc. (1930) 2579-2582, doi: https://doi.org/10.1039/ JR9300002579.

16. R. S. Cahn, C. K. Ingold, V. Prelog, Specification of molecular chirality, Angew. Chem. Int. Ed. 5 (1966) 385-415, doi: https://doi.org/10.1002/anie.196603851.

17. R. B. Woodward, F. Sondheimer, D. Taub, K. Heussler, W. M. McLamore, The total synthesis of steroids, J. Am. Chem. Soc. 74 (1952) 4223-4251, doi: https://doi.org/10.1021/ ja01137a001

18. L. B. Barkley, M. F. Farrar, W. S. Knowles, H. Raffelson, Q. E. Thompson, Studies in Steroid Total Synthesis. II. Correlation of Optically Active Bicyclic Intermediates with Natural Steroids1, J. Am. Chem. Soc. 76 (1954) 5014-5016, doi: https:// doi.org/10.1021/ja01649a003.
19. K. Tsuda, K. Tanabe, I. Iwai, K. Funakoshi, The structure of alantolactone, J. Am. Chem. Soc. 79 (1967) 5721-5724, doi: https://doi.org/10.1021/ja01578a037.

20. K. Tanabe, The structure of Alantolactone. The conversion of alantolactone into Dihydroeudesmol, Chem. Pharm. Bull. 6 (1958) 214-217, doi: https://doi.org/10.1248/cpb.6.214.

21. H. Matsuma, I. Iwai, E. Ohki, Sesquiterpenoids I. 3-Oxo-tetrahydroalantolactone, J. Pharm. Soc. Jpn. 74 (1954) 738741.

22. W. Cocker, T. B. H. Mcmurray, Stereochemical relationships in the eudesmane (selinane) group of sesquiterpenes, Tetrahedron 8 (1960) 181-104, doi: https://doi.org/10.1016/00404020(60)80028-2.

23. V. Benešová, V. Sýkora, V. Herout, F. Šorm, The absolute configuration of costol and alantolactone, Chem. and Ind. (1958) 363-364.

24. W. Cocker, T. B .H. McMurry, L. O. Hopkins, The chemistry of $\psi$-santonin. Part XI. Its absolute configuration, J. Chem. Soc. (1959) 1998-2003, doi: https://doi.org/10.1039/ JR9590001998.

25. W. Klyne, P. M. Scopes, A. Williams, Optical rotatory dispersion. Part XXVII. The Hudson lactone rule, J. Chem. Soc. (1965) 7237-7242, doi: https://doi.org/10.1039/ jr9650007237.

26. W. Klyne, P. M. Scopes, u G. Snatzke (ur.), ORD and CD in Organic Chemistry, Hyden \& Sons, Ltd., 1967., str. 193-207.

27. P. Crabbe, ORD and CD in Chemistry and Biochemistry, Academic Pres, 1972., str. 50-54.

28. H. W. Schmalle, Structure of $4 \beta, 10 \beta$-Dimethyleudesma-5,11(13)-diene-7 $\beta$-lactone (Alantolactone), Acta Cryst. (1986) C42 705-708, doi: https://doi.org/10.1107/ s0108270186094842.

29. J. Bijvoet, A. F. Peerdeman, A. J. van Bommel, Determination of the Absolute Configuration of Optically Active Compounds by Means of X-Rays, Nature 168 (1951) 271-272, doi: https://doi.org/10.1038/168271a0.

30. J. A. Marshall, N. Cohen, A. R. Hochstetler, Synthetic Studies Leading to dl-Telekin and dl-Alantolactone, J. Am. Chem. Soc. 88 (1966) 3408-3417, doi: https://doi.org/10.1021/ ja00966a041

31. A. Minato, T. Nagasaki, Synthesis of ( \pm )-atractylon, Chem. Commun. (1965) 377-379, doi: https://doi.org/10.1039/ C19650000377

32. A. Minato, I. Horibe, A new synthetic method for exocyclic methylene $\alpha \beta$-unsaturated $\gamma$-lactones and synthesis of ( \pm )-isoalantolactone Chem. Commun. (1965) 531-532, doi: https://doi.org/10.1039/C19650000531.

33. R. B. Miller, R. D. Nash, A Highly Stereoselective total synthesis of (+)-isoalantolactone, Tetrahedron 30 (1974) 29612965, doi: https://doi.org/10.1016/S0040-4020(01)97472-1.

34. G. Stork, S. R. Dowd, A New Method for the Alkylation of Ketones and Aldehydes: the C-Alkylation of the Magnesium Salts of N-Substituted Imines, J. Am. Chem. Soc. 85 (1963) 2178-2180, doi: https://doi.org/10.1021/ja00897a040.

35. S. S. Lim, J. R.Kim, T. Konishi, J. H. Y. Park, J. S. Kim, Induction of detoxifying enzyme by sesquiterpenes present in Inula helenium, J. Med. Food, 10 (2007) 503-510, doi: https://doi. org/10.1089/jmf.2006.209. 
36. A. K. Picman, R. H. Elliott, G. H. N. Towers, Insect feeding deterrent property of alantolactone, Biochem. Systematics and Ecology 6 (1978) 333-335, doi: https://doi. org/10.1016/0305-1978(78)90054-6.

37. A. Deriu, S. Zanetti, L. A. Sechi, A. Piras, S. Porcedda, E. Tuveri, Antimicrobial activity of Inula helenium L. essential oil against Gram-positive and Gram-negative bacteria and Candida sp., J. Antimicrob. Agents 31 (2008) 588-590, doi: https://doi.org/10.1016/j.ijantimicag.2008.02.006.

38. H.-L. Jiang, J. Chen, X.-J. Jin, J.-L. Yang, Y. Li, X.-J Yao, Q.-X. Wu, Sesquiterpenoids, alantolactone analogues and seco-guaiene from roots of Inula helenium, Tetrahedron 67 (2011) 91939198, doi: https://doi.org/10.1016/j.tet.2011.09.070.

39. J. Chun, R. J. Choi, S. Khan, D.-S. Lee, Y.-C. Kim, Y.-J. Nam, D.-U. Lee, Y. S. Kim, Alantolactone suppresses inducible nitric oxide synthase and cyclooxygenase-2 expression by down-regulating NF-кB, MAPK and AP-1 via the MyD88 signaling pathway in LPS-activated RAW 264.7 cells, Internat. Immunopharmacol. 14 (2012) 375-383, doi: https://doi. org/10.1016/j.intimp.2012.08.011.

40. A. Gokbulut, E. Sarer, Isolation and quantification of alantolactone/isoalantolactone from roots of Inula helenium subsp. turcoracemosa, Turk. J. Pharm. Sci. 10 (2013) 447-452.

41. N. J. Lawrence, A.T. McGown, J. Nduka, J. A. Hadfield, R. G. Pritchard, Cytotoxic Michael-type amine adducts ofa-methylene lactons alantolactone and isoalantolactone, Bioorg. \& Med. Chem. Letters 11 (2001) 429-431, doi: https://doi. org/10.1016/S0960-894X(00)00686-7.

42. C. L. Cantrel, S. G. Franzblau, N. F. Fischer, Antimycobacterial plant terpenoids, Planta Medica 67 (2001) 685-694, doi: https://doi.org/10.1055/s-2001-18365.

43. C. L. Cantrell, F. E. Dayan, S. O. Duke, Natural products as sources of new pesticides, J. Nat. Products 75 (2012) 12311242, doi: https://doi.org/10.1021/np300024u.
44. M. Khan, F. Yi, A. Rasul, T. Li, N. Wang, H. Gao, R. Gao,T. $\mathrm{Ma}$, Alantolactone induces apoptoses in glioblastiloma cells via GSH depletion, ROS generation and mitochondrial dysfunction, IUBMB Life 64 (2012) 783-794, doi: https://doi. org/10.1002/iub.1068.

45. T. Konishi, Y. Shimada, T. Nagao, H. Okabe, T. Konoshima, Antiproliferative sesquiterpene lactones from the roots of Inula helenium, Biol. Pharm. Bull. Jpn. 25 (2002) 1370-1372, doi: https://doi.org/10.1248/bpb.25.1370.

46. F. Li, D. Liu, Method for preparing alantolactone and isoalantolactone simultaneously, IPC C07D307/92 CN 102558120 (A), 11. 7. 2012.

47. G. Banerjee, P. M. Dias, R. Kalathil, Plant extract of inula racemose, PCT/EP2014/051590, WO 2014124803 A1, 21. 8. 2014.

48. X.-F. Chi, H.-L. Yue, X.-H. Zhao, F.-Z. Hu, Obtaining alantolactone and isoalantolactone from Inula racemose Hook.f. by optimized supercritical fluid extraction, Ind. Crop. Prod. 79 (2016) 63-69, doi: https://doi.org/10.1016/j.indcrop.2015.10.025.

49. L. Sang Kook, M. Hye Yeong, Composition of Inula helenium L. extract or alantolactone or isoalantolactone isolated therefrom for prevention and treatment of cancer or inflammatory deseases, IPC A61K35/78, KR Pat. 20040107185, 20. 12. 2004.

50. Y. Yang, H. Wan, H. Xy, L. Zhang, C. Yan, Medical use of volatile oil traditional chinese medicine, CN 101002812 A, 25. 7. 2007.

51. Market Publishers, Alantolactone (CAS 546-43-0) Market Research Report 2015 (1. 1. 2016.), URL: https://marketpublishers.com/r/AC7B6ED70A0EN.html.

52. Q.-X. Wu, a Y.-P. Shi, Z.-J. Jiaa, Eudesmane sesquiterpenoids from the Asteraceae family, Nat. Prod. Rep. 23 (2006) 699734, doi: https://doi.org/10.1039/b606168k. 


\section{SUMMARY}

\section{On Helenine from Srećko Bošnjaković to Lavoslav Ružička - Model Example for Development of Organic Chemistry in $20^{\text {th }}$ Century \\ Vitomir Šunjić*}

Prof. Srećko Bošnjaković (1865-1907) is considered as the first Croatian chemist who completed $\mathrm{Ph}$. D. thesis in the field of organic chemistry. In his thesis published in 1893 under the title "Gerhardt's Helenine" S. Bošnjaković has described isolation of helenine from the roots of Inula helenium L., separation of chemically pure substances and determination of their empirical formulae by elemental analysis. In his thesis the names helenine and alantolactone were used, the second one appears exclusively in the recent literature. Since this name indicates existence of lactone group in helenine it was interesting to investigate what was known at that time about the structure of this natural product, in particular who has determined exact structure of alantolactone and its isomers and congeners, sesquiterpenes present in the Nature. It turned out that our Nobel laureate Lavoslav Ružička greatly contributed to the knowledge of this field, who in the period 1931-1936 investigated structures of numerous sesquiterpenes and formulated well-known Ružička's biogenetic isoprene rule ( $L$. Ružička, The isoprene rule and the biogenesis of terpenic compounds, Experientia 9 (1953) 357-396).

Prompted by this unexpected "Croatian connection by helenine", I have discovered interesting development of chemistry related to alantolactone, in particular contribution of Lavoslav Ružička to structure determination.

In this review the work of Bošnjaković and Ružička is presented and new results revealed on structure determination, synthesis and important biological properties of alantolactone and related sesquiterpenes. Most recent results and accumulated knowledge on alantolactone represent an excellent example for development of organic chemistry in the $X X^{\text {th }}$ century.

\section{Keywords}

Inula helenim L., helenine, alantolactone, structure, stereochemistry, biological activity, history of science

Croatian Academy of Sciences and Arts

Review

Zrinjski trg 11

10000 Zagreb

Croatia

Received March 1, 2016 Accepted April 11, 2016 